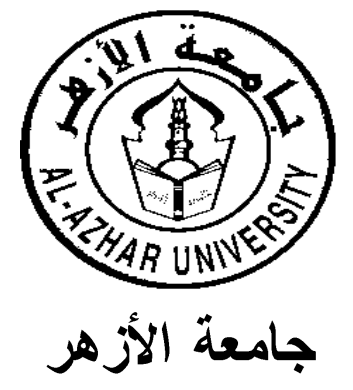

كلية الار اسات الإسلامية والعربية للبنين بقنا المجــلة العلميـــة

\title{
سورة الفاتمة
}

\section{جامعة الإقاصد وناجعة القاصد}

\author{
إعداد \\ د دامي حسن سيف عثمان \\ دكتور اه في التفسير وعلوم القرآن \\ ( العدد الثامن عشر اY • ( م )
}




\section{سورة الفاتهة جامعة المقاصد وناجعة القاصد}

سامى حسن سيف عثمان قسم التفسير وعلوم القرآن، وزارة الأوقاف، الجامعة: الأزهر: المدينة: قنا، الدولة:

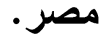

البريد الإكتروني: Duaa.metawi@gmail.com

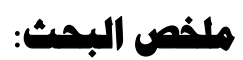

سورة الفاتحة أم القرآن اشتملت على مقاصده وأهدافه من التوحيد والبعث والجــزاء والعبادة وطلب الهداية وقصص الأولين من الأنبياء والصــالحين والمغضــوب علـيهم و الضالين لذلك كانت جامعة المقاصد وفيها إثـارات إلى تعليم المسألة وتدرج العبد فـى مدارج الهاية فمن التزم منهجها بلغ المقصود من قصدها استفتاحاً لأمر أو تبرك بهــا ويأسرارها كانت كافيه وهى ناجعة القاصد فأنتثمل هذا البحث على ما دلت عليه الفاظها

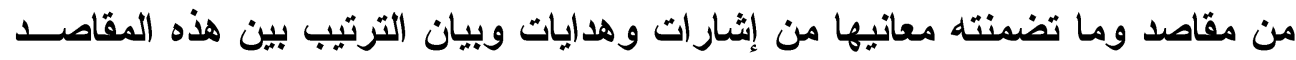
وكيف أنبنى اللاحق على السابق من عباراتها حتى أوعت واستوعبت الكثير من المعساني

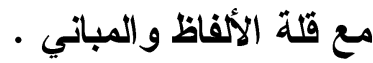
الكلمات المفتامية: الفاتحة، المقاصد، التوحيد، البعث، القصص، الهداية، العبادة،

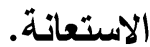


Surah Al-Fatihah gathering of Al-Maqasid and the Effectiveness of Al-Qasid

Sami Hassan Seif Othman

Department of: Interpretation and Sciences of the Qur'an, College: Islamic and Arabic Studies for Boys in Qena, University: Al-Azhar: City: Qena, Country: Egypt.

E-mail: Duaa.metawi@gmail.com

\section{Abstract:}

Surat Al-Fatihah, Mother of the Qur'an, included its purposes and objectives of monotheism, resurrection, reward, worship, seeking guidance, and the stories of the early prophets, the righteous, and those who were angry with them. And the misguided, for this reason was gathering of the purposes and in it there were references to the teaching of the matter and the gradation of the servant in the paths of guidance, so whoever adhered to its approach reached the purpose of its intention to open an order or to be blessed with it and its secrets, it was sufficient and it was effective for the purpose. Between these purposes and how the later was built on the previous from its phrases until it understood and absorbed many meanings with the lack of words and premises.

Keywords: Al-Fatihah, Purposes, Monotheism, Resurrection, Stories, Guidance, Worship, Seeking help. 


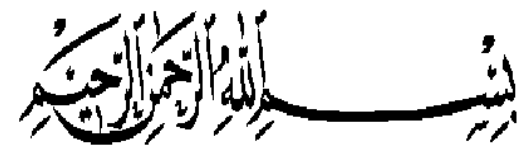

\section{مقدمة}

العمد الله رب العالمين والصلاة والسلام على خير خلق الله سيدنا محمد وعلــى آلـــه و أصحابه التابعين، وبعد

فقد سعدت بمعايشة سورة الفاتحة ودراسة مقاصدها فوجدتها جمعت أصول القـــرآن

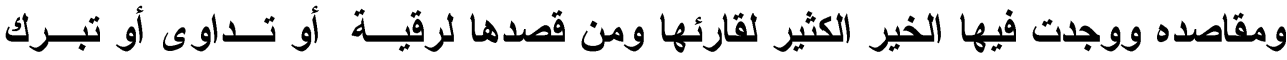

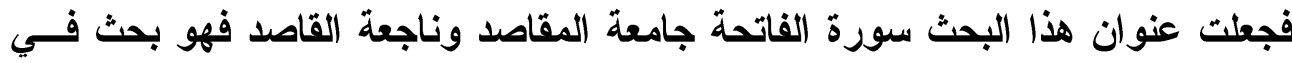

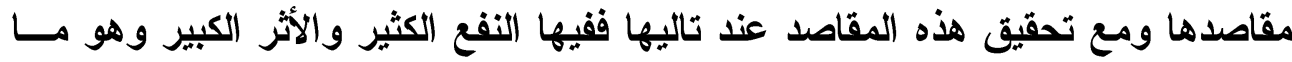

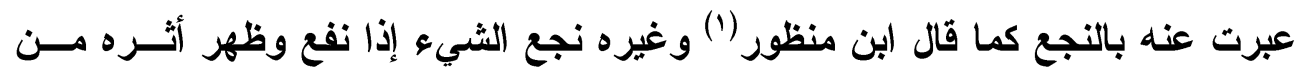

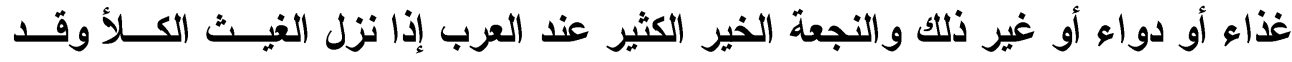
سلكت أهذا البحث على غير عادة المفسرين حيث يصدرون تفسيرهم بذكر مقاصد السور

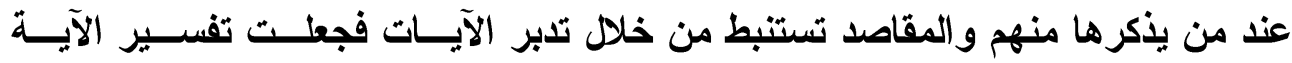

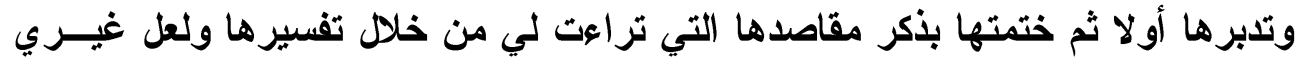

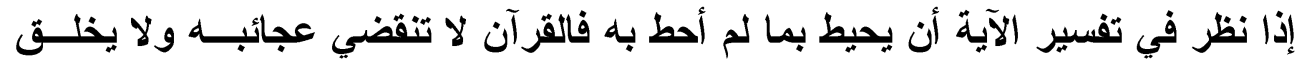

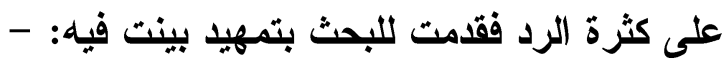
أولاً: - معني المقاصد وأهميتها وطرق معرفتها ومر احل دراستها. ثانيـا: - التعريف بسورة الفاتحة ونزولها وأسمائها وفضلها وكيف جمعسـ أمهــات

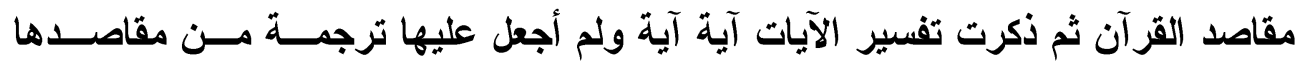

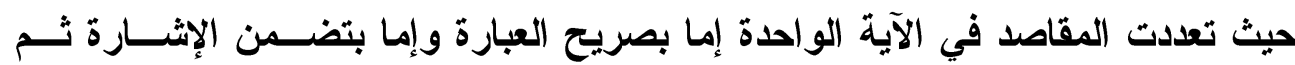
عرضت مجملا لأسلوب الفاتحة في ذكر مقاصدها ثم الخاتمة و المصادر .

(1) - (1) لسان العرب لابن منظور 
أستأل الله أن يستعملني ولا يستبلني ولا يحرمني فضل هذه السورة المباركة وبركسـة القرآن العظيم و المسلمين أجمعين.

\section{أولاً: - التعريف بالاتقاصد وأهميتها: -}

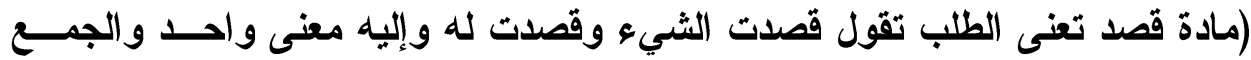

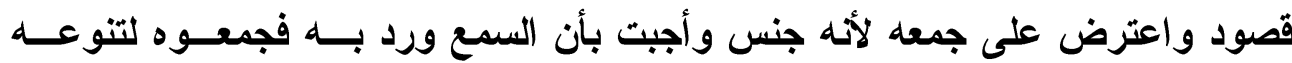

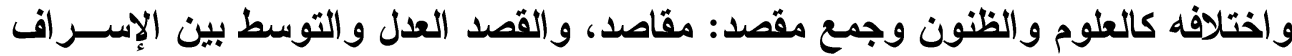
و البخل والقاصد القريب والقصد الرشد والمقصد بفتح الصاد المصدر وبكسـرها مكسـان القصد وقصد في الأمر أي توسط وطلب الأسد وطريق قصد أي سهل) ('). وحاصل ما هنالك أن القصد: يدل على الطلب ومن ذلك يتضح أن مقاصد القــرآن مـــ

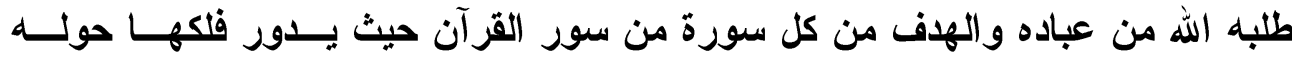
وتتصل آياتها بيانا لهذا الهذف وقد يكون جليا في مطلعها أو مستنبطا اسـتقر اء إياهـــا

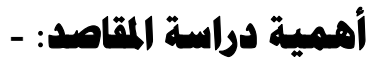
1- تدبر القرآن حيث إنه هو الطريق للوقوف على المقاصد r- بساعد الفهم المقاصد على تفسبر الآيات وفقا للحكمة التي ســقيقت مسن أجلهـ و الموضوع الذي تدور حوله.

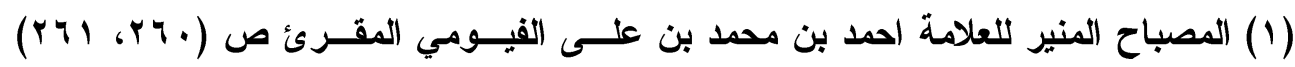

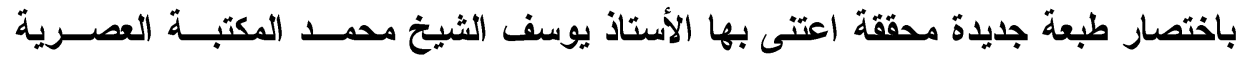

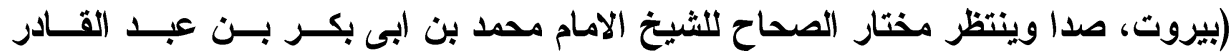
الزازي ص (عهم) المكتبة العصرية (صدا-بيروت). 


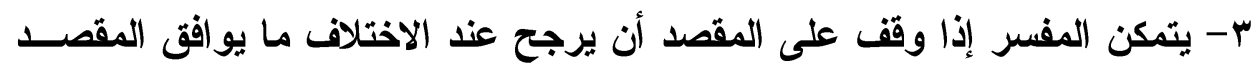

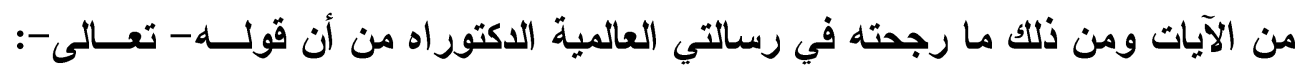

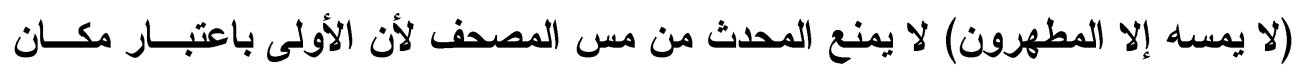

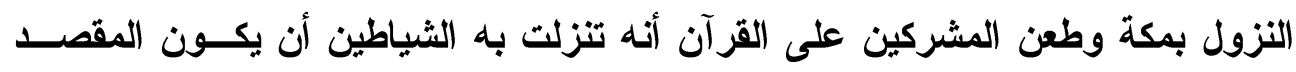
منها الدفاع عن القرآن. ع - بمعرفة مقاصد سور القرآن يهتدي الخلق إلى مراد الحق - عز وجل- وبالمثــال

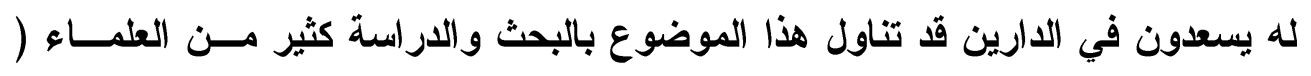

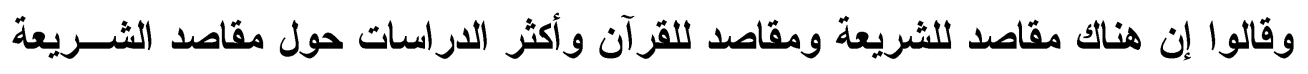

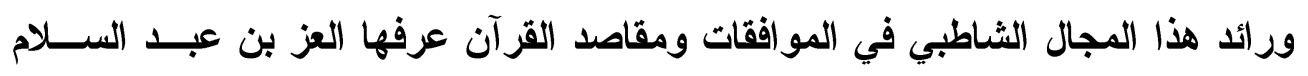

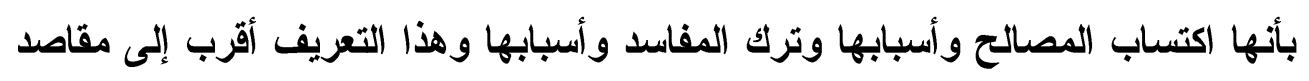

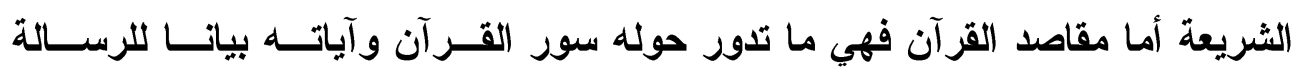

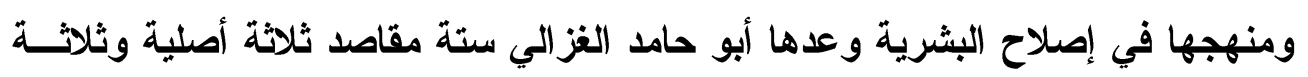

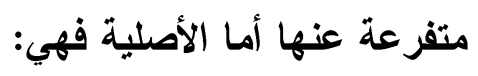
1- التعريف بالله عز وجل. r-الطريق المستقيم إليه. r-أحوال الو اصلين إليه و التابعة لهذه الثلاثة.

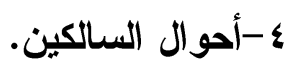
ه - محاجة الجاحدين.

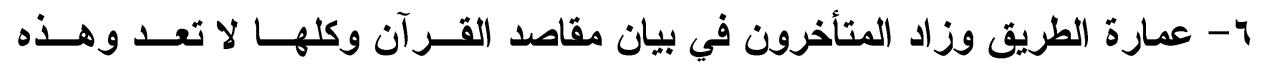
الأصول فكتب فيها. - V (الطاهرين عاشور، ومحمد رشيد رضا، وعزت دروزه). 
وكتب الشيخ مسمد الغزالي كتابة الماود الفمسة للقران الكريم:

$$
\text { المعور الأول: - الله الواحد. }
$$

المور الثاني: - الكون الدال على خالقه.

المهور الثالث: - القصص القر آني.

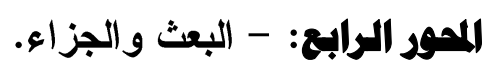

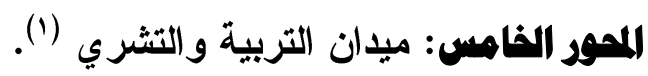

(والمحاور: جمع محور وهو المركز الذي يدور حوله الموضوع و المحاور والمقاصد

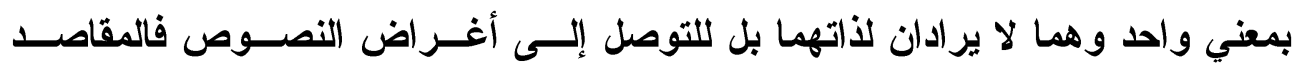

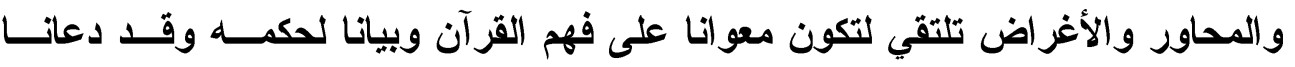
القرآن لذلك قال تعالى: (يريد الله بكم اليسر ولا يريد بكم العسر) (؟). وقال تعالى: (لكيلا تأسوا على ما فاتكم ولا تفرحوا بما آتاكم) (r).

وقال تعالى: (إنا أنزلنا إليك الكتاب بالحق لتحكم بين الناس بما أراك الله)، (ईٔ) وغيرها

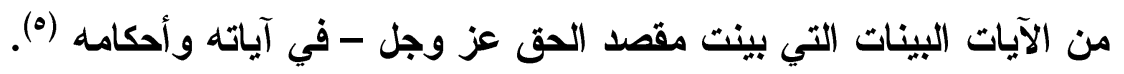

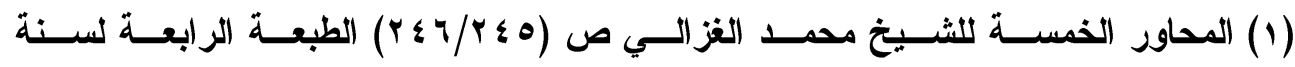

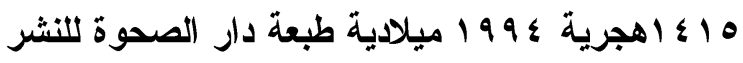

$$
\begin{aligned}
& \text { (r) سورة البقرة (r) (1). } \\
& \text { (Y) سورة الحديد (T) (Y). }
\end{aligned}
$$

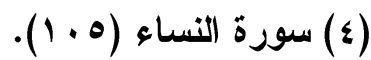

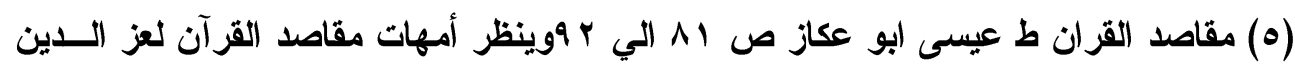

$$
\text { كشنيط رسالة دكتور اة بالجزائر. }
$$




\section{ثانيا: - التعريف بسورة الفاتهة:}

سورة الفاتحة مكية عند أكثر أهل العلم (1) وهو الصحيح لأهه لا يعرف فـي الإسـلام

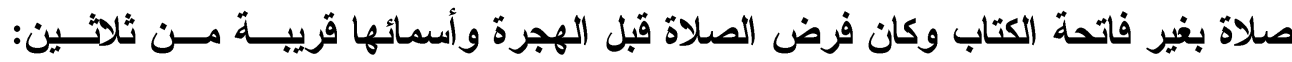

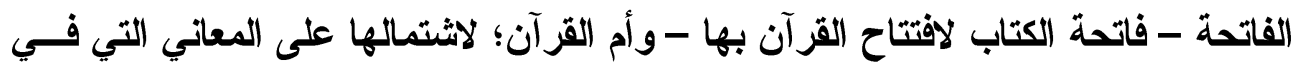

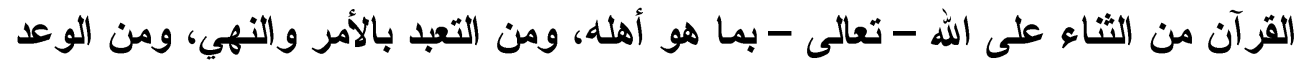

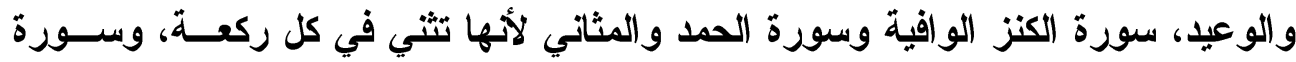

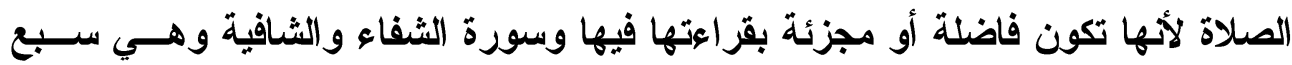

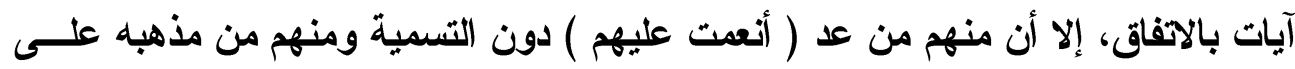

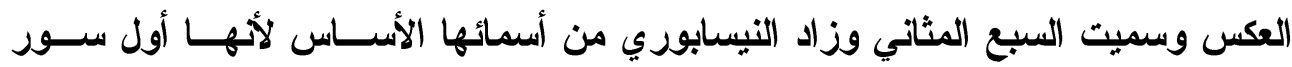

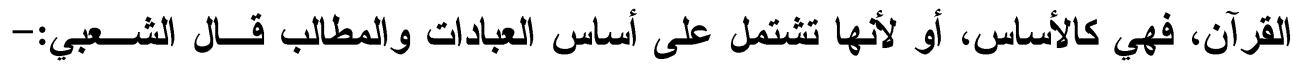

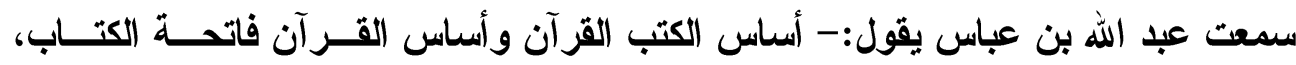

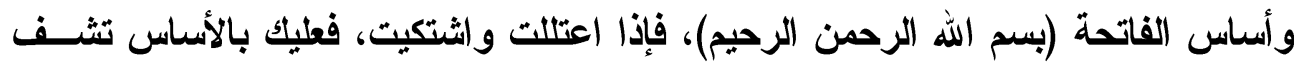

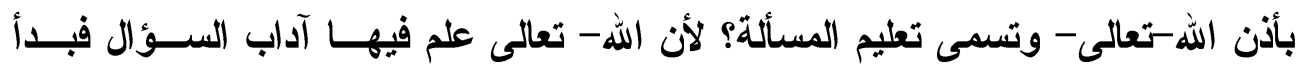

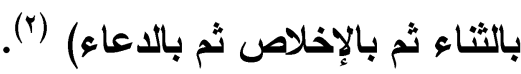
وتسمى الرقية لقوله - :- لمن رقى بها (وما يدريك أنها رقية قال بــا رسـول الله

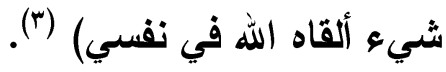

(1) بصائر ذوي التمييز في لطائف الكتاب العزيز تأليف مجد الدين محمود بن يعقوب القيـروز

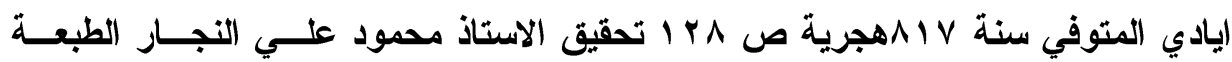

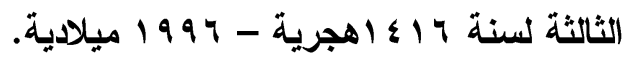

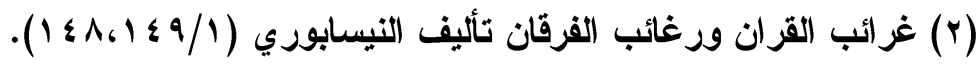
(r) صحيح بين حبان صז r البأخرجه في صحيحة. 
((1)

((يتجلى فضل هذه السورة الكريمة في كثرة أسمائها فكثرة الأسماء شرف للمســى (ألى روى الترمذي عن أبى بن كعب قال: قال رسول الله - :--: ما أنزل الله في التوراة ولا

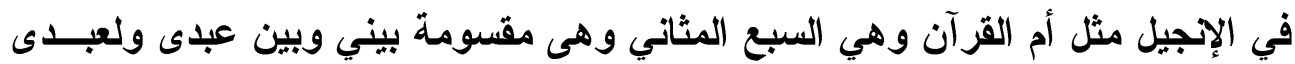

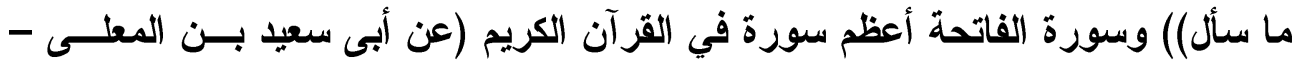
رضى الله عنه قال: كنت أصلى في المسجد فدعاني رسول الله :- فلم أجبه حتى صليت فقلت: يا رسول الله إني كنت أصلى فقال:

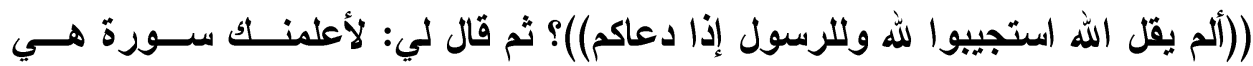

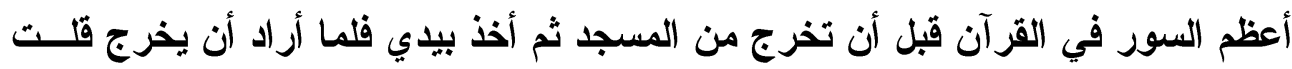
لله ألم تقل لأعلمنك سورة هي أعظم السور في القرآن؟ قال(( الحمـــ لله رب العــالمين؟

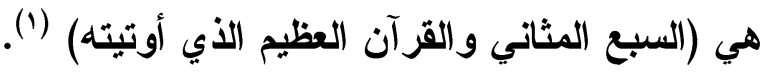

\section{سورة الغاتشة أفضل القرآن :}

عن أنس بن مالكك - رضي الله عنه - قال: - كان - صلي الله عليه وســلم - فــي مسير لله، فنزل، ونزل رجل إلى جانبه، فالتفت إليه النبي -:-فقال: (ألا أخبرك بأفضـل

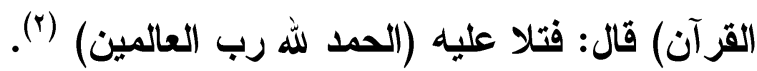

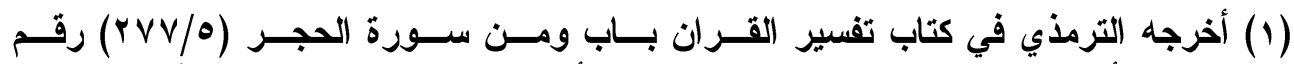

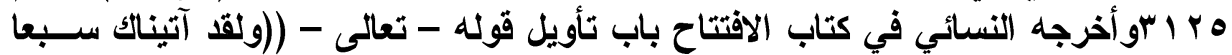

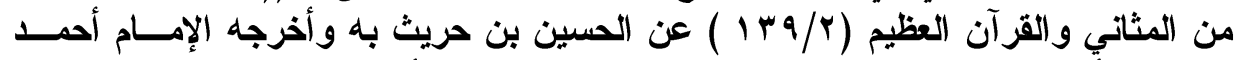

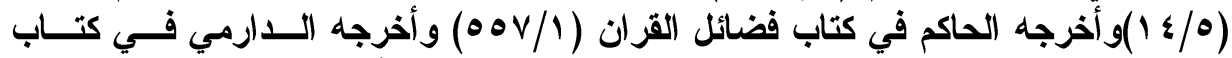

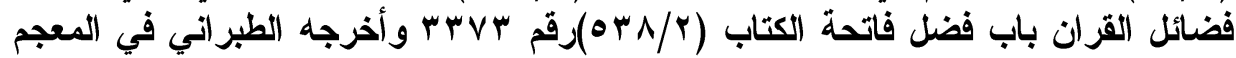

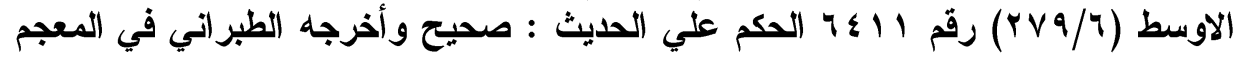

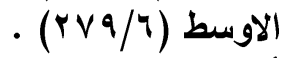

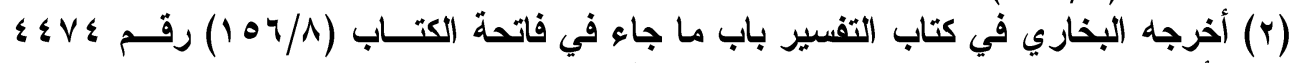

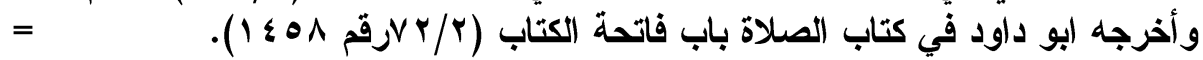


(روي مسلم والنسائي عن ابن عباس قال: - بينما جبريل قاعد عند النبي -صلي الله

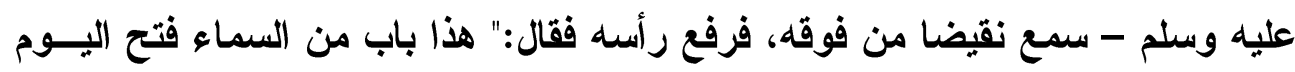

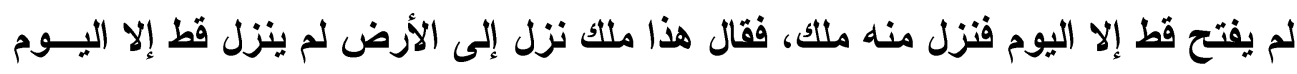

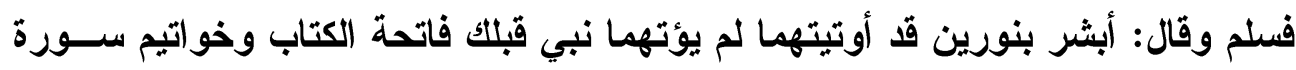

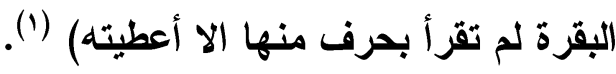

\section{جمع الفاتثة المقاصد القرآن}

جاء القرآن لمصالح العباد في المعاش والمعاد وصلاحهم مرهون بالعبادة لأن الخالق

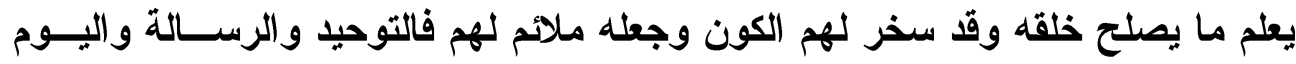

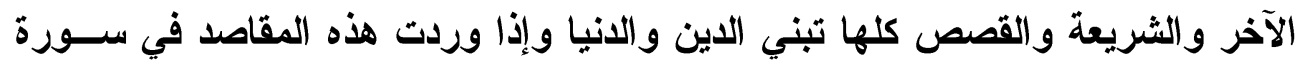
القرآن وأخذت كل سورة بحظها فقد جمت الفاتحة هذه المقاصد كلها.

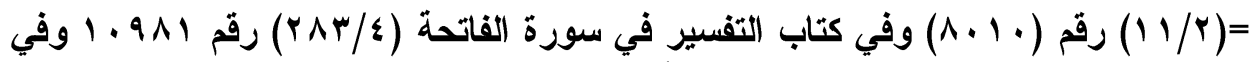

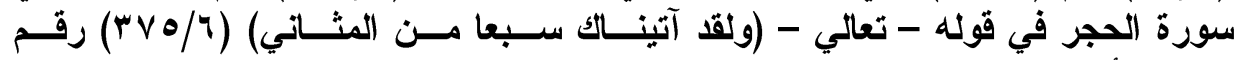

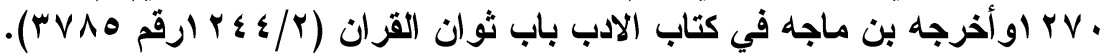

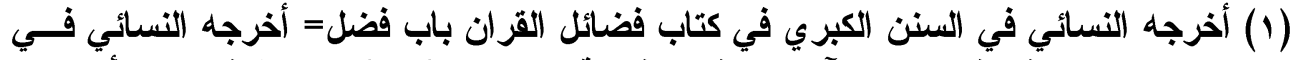

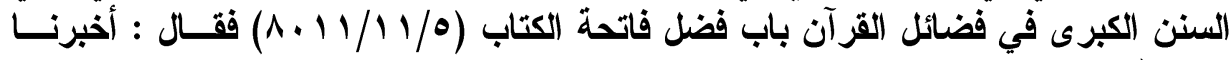

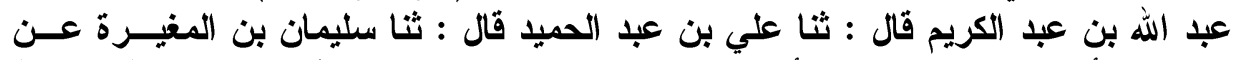

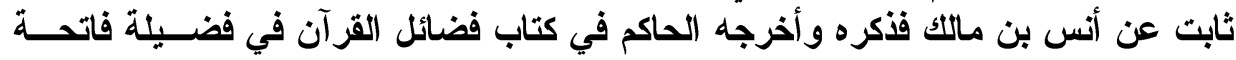

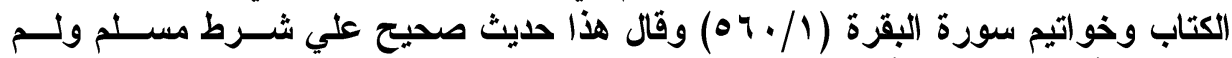

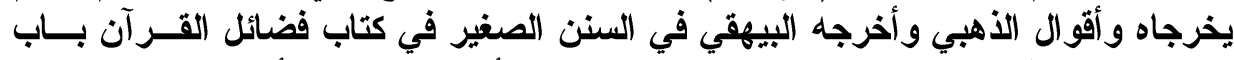

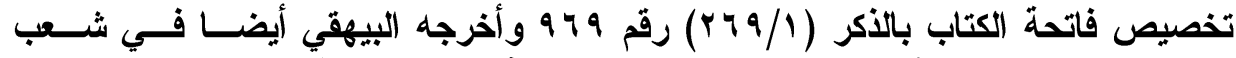

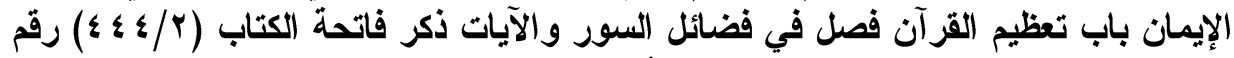

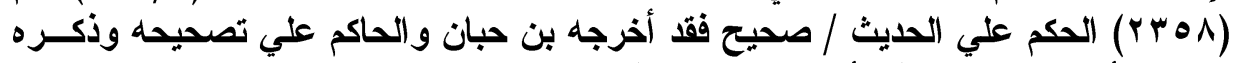

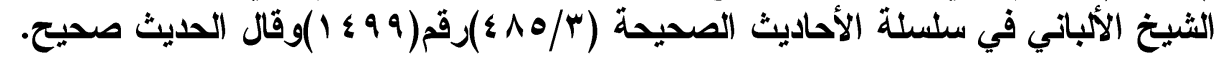




\section{يقول الشيخ هبد الدين الفيروز آبادي: -}

( المقصود من نزول هذه السورة تعلم العباد التيمن والتبرك باسم الله الرحمن الرحيم

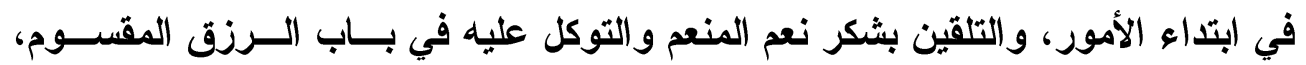

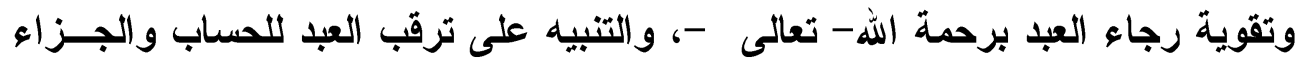

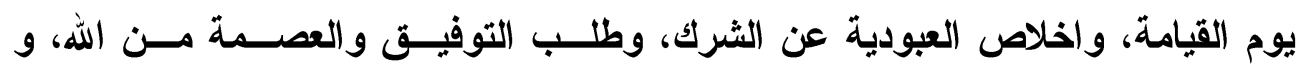

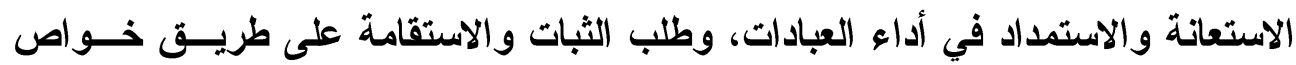

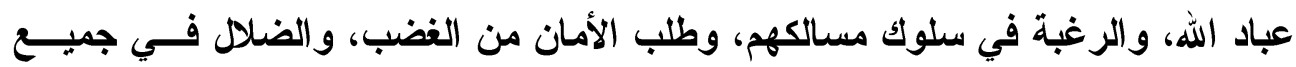

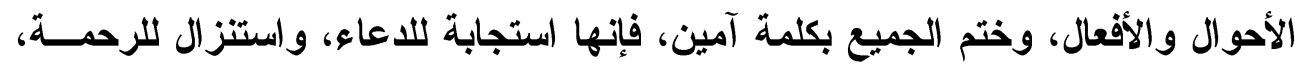

وهي خاتم الرحمة التي ختم بها فاتحة (لكتاب)(').

\section{يقول الأستاذ أهمد مصطفي المراغي: -}

(سميت الفاتحة أم الكتاب، أم القرآن لاشتمالها على مقاصد القرآن من الثناء على الله و التعبد بأمره ونهيه وبيان وعده ووعيده).

يقول الدكتهر عبد الاله شماته جمعت الفاتهة أصول الإيمان وأهداف القرآن (ז).

(و المتتبع لأهداف القرآن الكريم الواقف على مقاصده ومعارفه يرى أنه جاء تفصـيلا

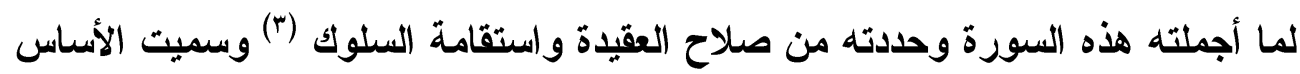

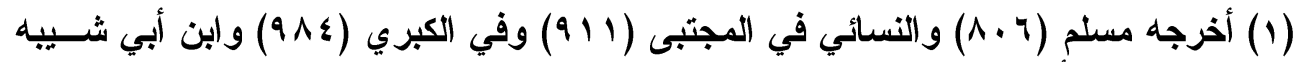

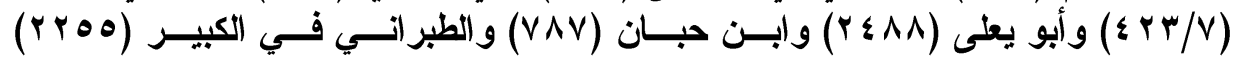

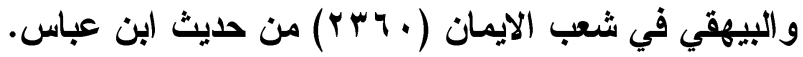

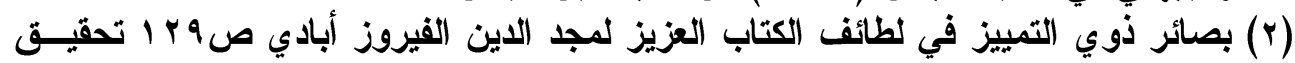

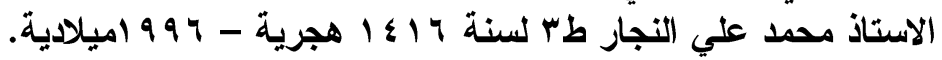

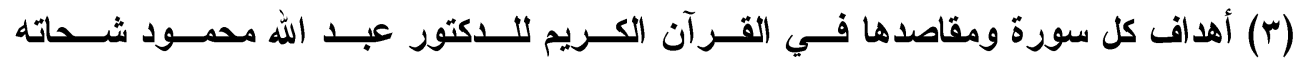

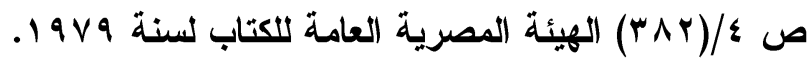


لأنها أصل القر آن فهي مشتملة على مقاصد القرآن إجمالا ثم فصل القرآن مــا أجملتـهـ الفاتحة وبيان هذا أن القرآن الكريم اثتتمل على التوحيد؟ وعلى وعد من أخذ به بحسن التهن المثوبة ووعيد من تجافى عنه وتركه بسئ العقوبة؟ وعلى العبادة التي تحي التوحيد في القلوب وتثبته في النفوس؟ وعلى بيان سبيل السعادة الموصل الى نعيم الدنيا والاخــرة؟ وعلى القصص الحاوي أخبار المهتدين الذين وققوا عند الحدود التي سنها الله لعبـاده،

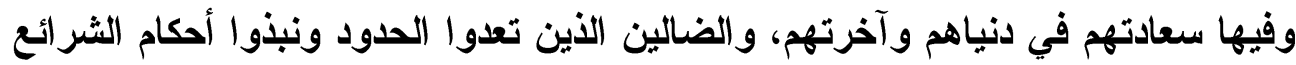

وراءهم ظهريا وقد حوت الفاتحة هذه المعاني جملة ('). وقد يقول قائل: قد تكون سورة غيرها من سور القرآن حوت هذه المقاصد أو أكثرها فلم جعلتها جامعة المقاصد وحدها؟ أقول غيرها قد يقرا بعضها ويقف القارئ على أي جزء منها أمـا هذه فهي الوافيــة التي تقر أ كاملة.

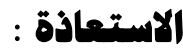

ورد الاختلاف في عد البسملة آية من الفاتحة فعدها الكوفيون والمكيون ولــم يعــها

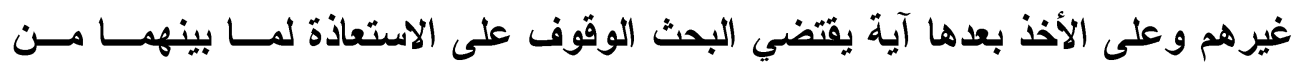

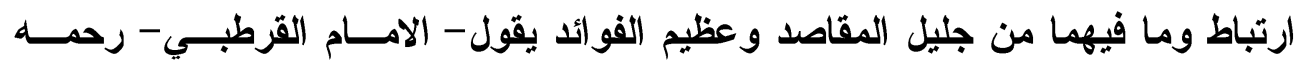

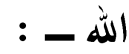
(أمر الله - تعالى - بالاستعاذة عند أول كل قراعة فقال - تعـالى: - (فـإذا قـرأت

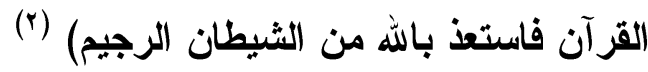
(1) تفسير المر اغي تأليف صاحب الفضيلة الأستاذ الكبير المرحوم أحمد مصـطفي المراغـي استاذ الثريعة الاسلامية واللغة العربية بكلية دار العلوم سابقا.

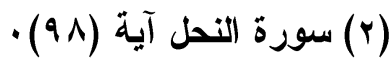


أي إذا أردت ان تقرأ، فأوقع الماضي موقع المستقبل (').

\section{وتجبي مقاصد الاستعاذة في هذه الأممر: -}

الأول: - أعوذ بالله عروج من الخلق إلى الحق ومن الممكن إلى الواجـب لأن أعــوذ

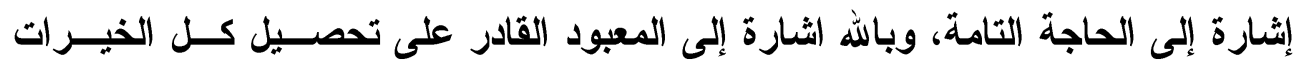
ودفع كل الآفات، ومن عرف نفسه بالضعف والقصور عرف الله بأنه قــادر علــى كـلـل

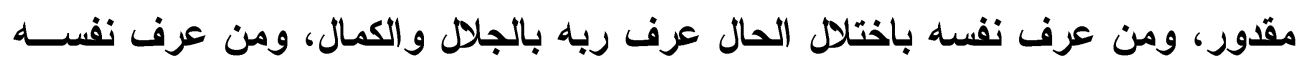

$$
\text { بالإمكان عرف ربه بالوجوب ومن عزف بابه }
$$

الثـاني: - سر الاستعاذة الالتجاء إلى قادر يدفع عنك الآفات وقراعة القرآن من أعظم أعاء

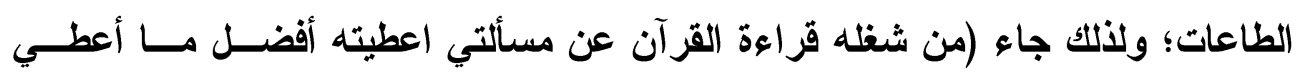
السائلين) فلهذا خصت الاستعاذة بالقراءة.

الثالث: - عند القرار من العدو الغدار يقول: أعوذ بالله من الثيطان، وبعد الاستقرار في حضرة الملك الجبار يقول: بسم الله الرحمن الرحيم. الرابع: - الاستعاذة تطهر اللسان عم جرى عليه مــن ذكـر غيــر الله؟ وإذا حصـل الطهور استعد للصلاة الحقيقة وهي ذكر الله؟ فيقول بسم الله. الغامس : - إذا حاربت العدو الظاهر كان مددك الملايكة (يمددكم ربكم بخمسـة الآلاف

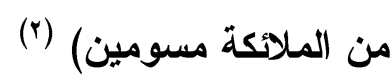

(1) الجامع لأحكام القرآن تفسير القرطبي لأبي عبد الله محمد بن أحمد الآصــاري (1/ع 1) تحقيق إبر اهيم محمد الجمل.

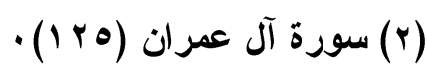


وإذا حاربت العدو الباطن كان مددك الملك (إن عبادي ليس لك عليهم بسلطان) (1) (لأن العدو الظاهر إن غاب كنا مفتونين، ومن قتله، ومن قتلة العــدو الظــاهر كــان

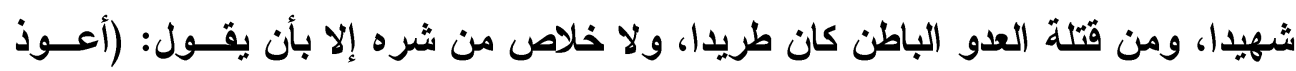

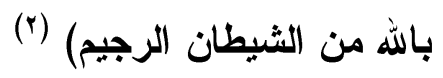

(أجمع العلماء على أن التعوذ ليس من القرآن ولا آية منه)، وهو قول القارئ:

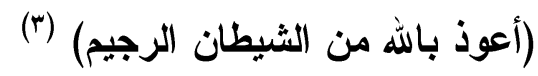

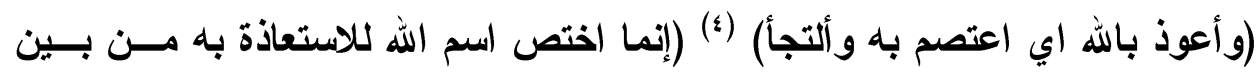

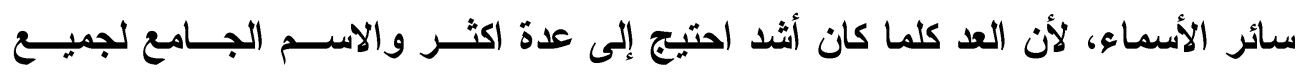

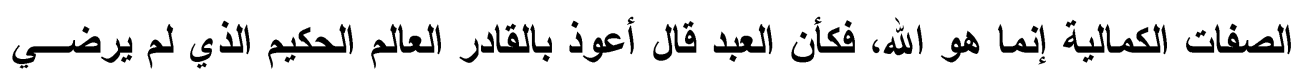
بشيء من المنكرات من الثيطان الرجيم) (ه).

(والشيطان من شيط أي: احترق أو من شطن أي: بعد) (†). (وسمي الثيطان شيطانا لبعده عن الحق وتمرده، وذلك أن كل عات متمرد من الجـن تيطن

والانس و الاواب شيطان) (v)

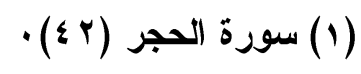

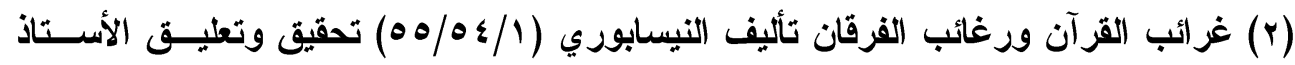

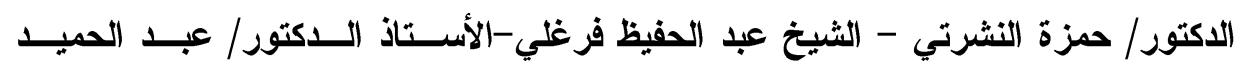

$$
\begin{aligned}
& \text { مصطفي. }
\end{aligned}
$$

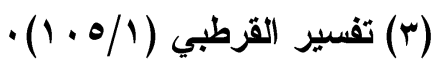

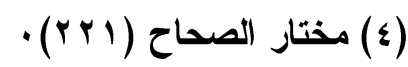

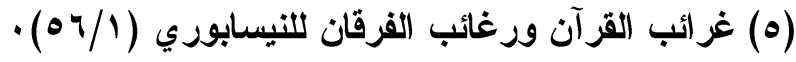

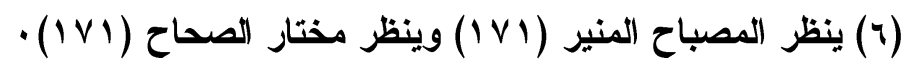

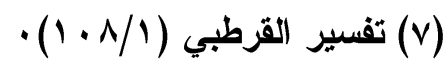


(و الرجيم رجم - الرجم القتل، وأصله: الرمي بالحجارة وبابه نصـر فهـو (رجـيم)

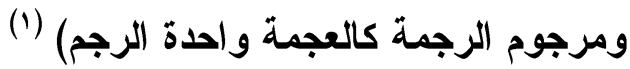

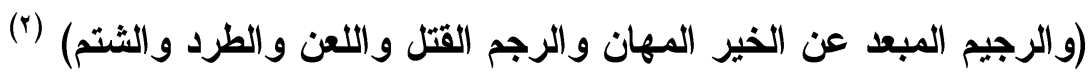

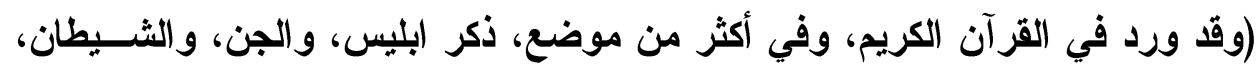

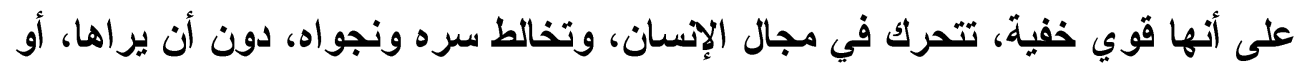

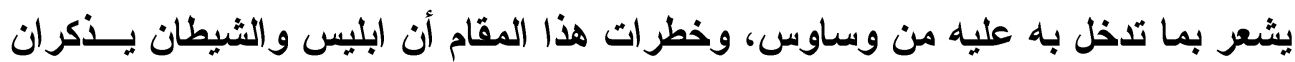

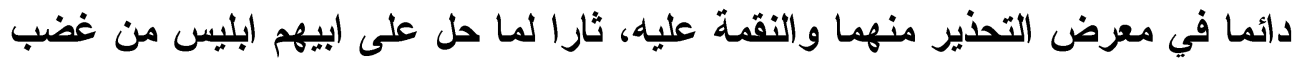
الله ولعنته حين أبى أن يستجيب لأمر الله بالسجود لآدم ..

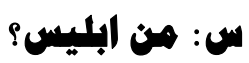

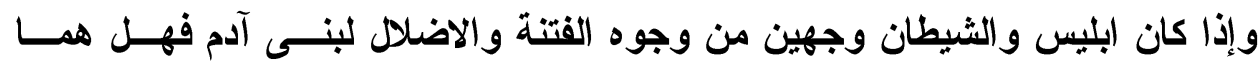

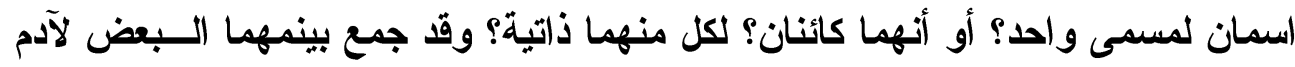

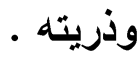

وكان من ذللك تحذير من الله - تعالى - لآدم وذريتـهـ منههــ؟ و التتبيـه ولغــدرهما

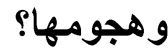

كلما غفل عنهما الإسان؟ والذي ينظر في القرآن الكريد؟ ويتتبع المو اقف التي ذكـر

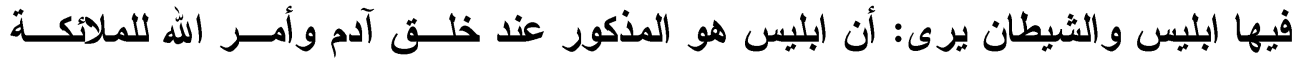

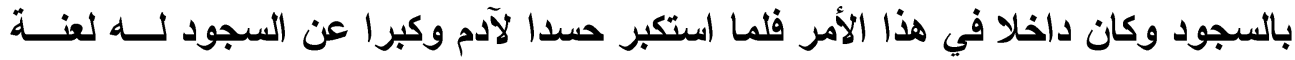

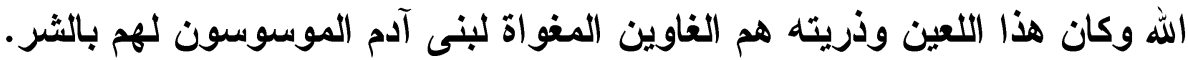

$$
\text { (1) تفسير القرطبي (1) (1) (1) (1) ). }
$$


أمـا الجن فانه يتضح مما جاء في القرآن الكريم عنهج؟ أنهم من طيعة قابلــة للخيـر

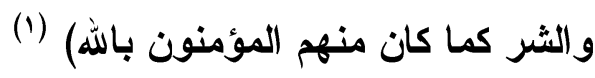

فأمر الله عباده أن يستعيذوا به ليحفظهم من شر الثياطين وأفرد للتعوذ من شياطين

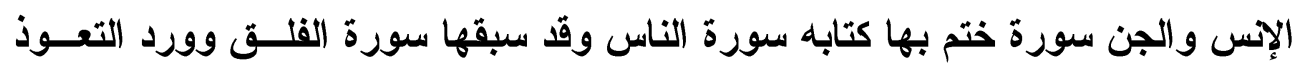

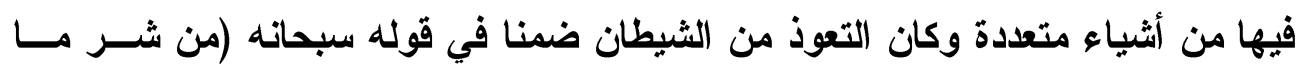

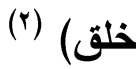
إلا أنه ورد صريحا لأهميته في سورة مستقلة لم يذكر معه غير لطفا من الله بعبـاده

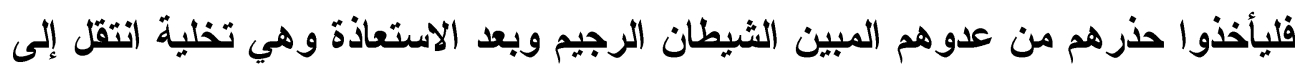

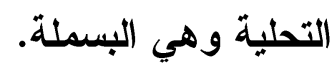

\section{(الآية الأولى البسملة)}

يقول الفخر الرازي عن الارتباط بين الاستعاذة والبسملة (أعوذ باله إثارة إلى نفي

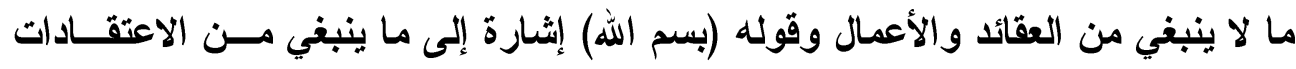

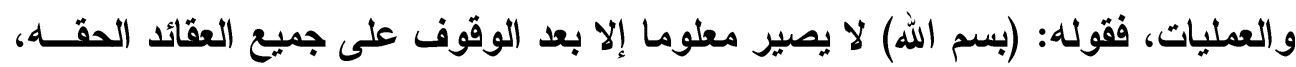

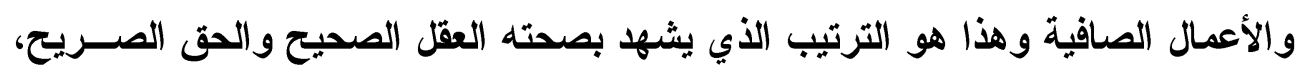

و الباء للإلصاق (أي: بسم الله أثرع) (r).

(1) الثيطان و الإنسان بين أوليائه وأعدائه الثيخ عبد الكريم الخطيب (ع / ^ 1) ط دار الفكر

$$
\begin{aligned}
& \text { العربي. } \\
& \text { (r) سورة الفلق (r) - (r) }
\end{aligned}
$$

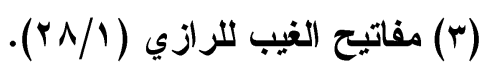


1- والمقصود من التسمية: قول الإسسان (بسم الله) أما البسملة فهي قول (بســم الله

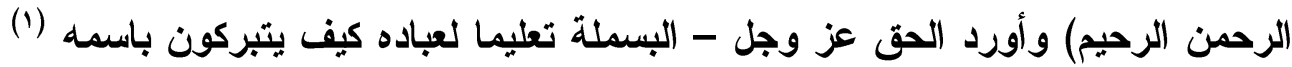

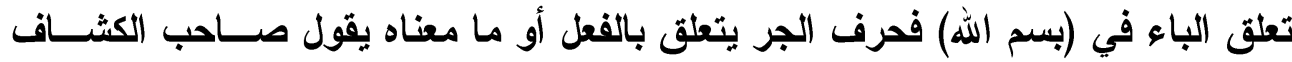

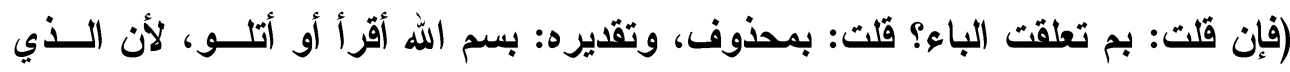
يتلو التسمية مقروء، كما أن المسافر إذا حل أو ارتجل فقال: بسم الله والبركسـات، كــان

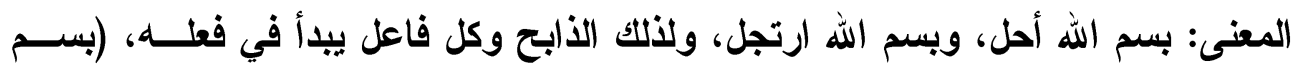

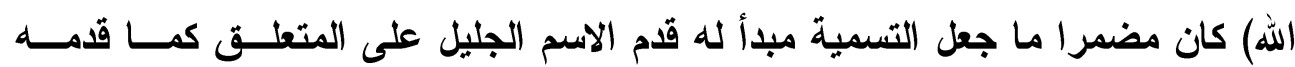

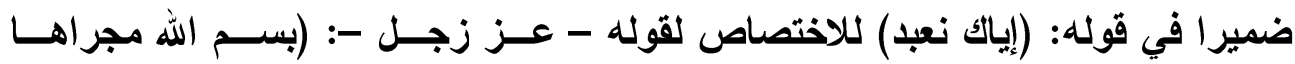

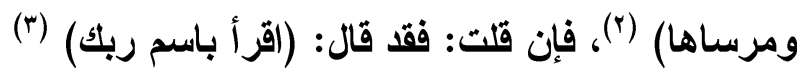
فقدم الفعل، قلت: هناك تقديم الفعل اوقع لأنها أول سورة نزلت فكان الامر بـالقراءة أهم . (₹)

(الباء للإلصاق أي: بسم الله أثرع) (ه) (الثرع) (وهو من الأسماء المحذوفة الإعجاز: كيد ودم، وأصــله: ســو بـدليل تصــريفه:

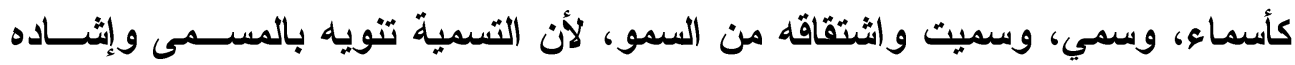

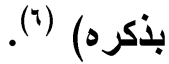

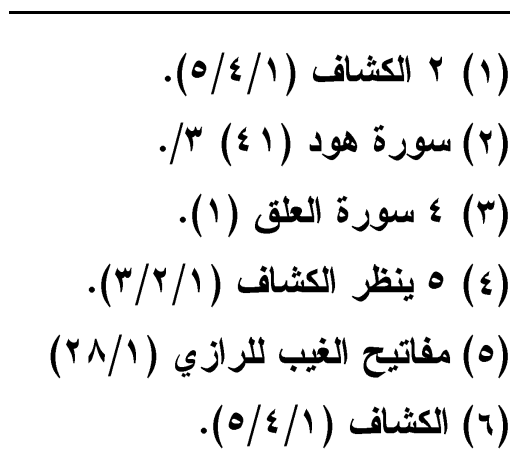


(و الباء في (بسم) للالتصاق فهو يوصل العبد إلى الرب وهو نهاية المطلب وأقصى الأمســ

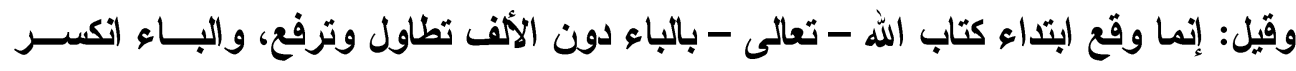

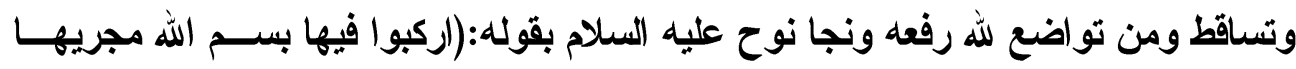

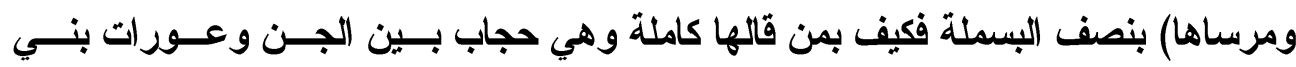

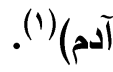

قال الإمام القرطبي: - (الله) هذا الاسم أكبر أسمائه - سبحانه - وأجمعها حتى قــال

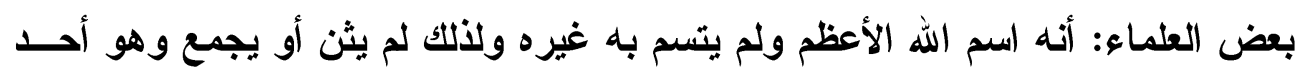
تأويلي قوله - تعالى -: (هل تعلم له سميا) (†). أي: من تسمي باسمه الذي هو: (الله) فالله اسم للإلهه الحق الجـامع لصــفات الألوهيــة

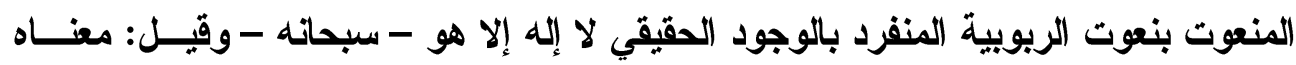

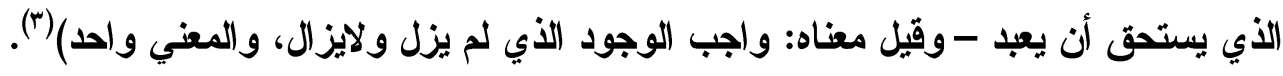
واختلف العلماء في هذا الاسم هل هو مشتق أو علم للأت العلية غير مشتق؟ على قولين: - القول الأول: - أنه مشتق وهو على وجوه: 1. أنه مشتق من أله بالفتح فيهما (ألاهه) أي عبد. r.أنه من أله أو تحير وبابه طرب وأصله وله يوله ولها. (فالله سبحانه تتحير الألباب وتذهب في حقائق صفاته والفكر في معرفته) (\{).

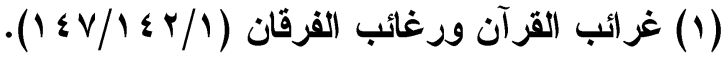

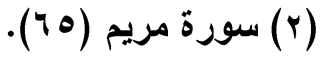

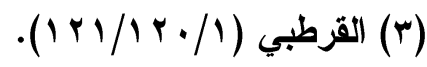

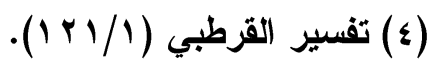


r. أنه مشتق من قولهم ألهت إلى فلان أي فزعت البه لأن الخلق يـألهون اليـــه أي

يفزعون الي الله (').

ع. قيل إن لاه يليه إذا ارتفع، لارتفاعه؟ - تعالى - عن مشابهة المثليات .

ه. من لاه يلوه إذا احتجب لاحتجابه - تعال - عن العيون.

4. قيل أصله لاه البرق يلوه إذا لمع وأضاء لإضاءة القلوب ولمعانها بذكره - تعسلى

- ومعرفته (ץ)

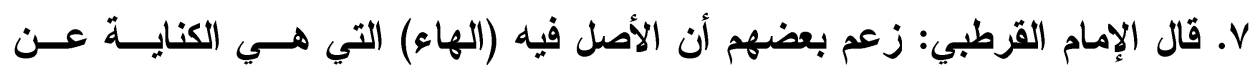

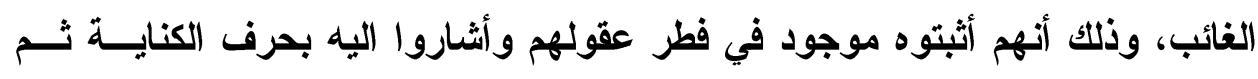

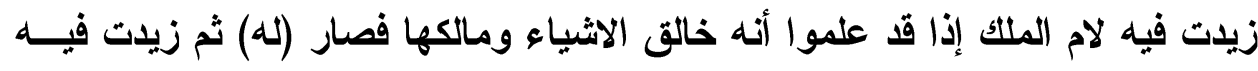

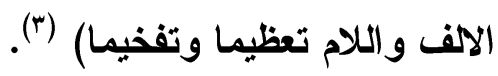

إلى غير ذلك من الاقوال التي تقول بأن لفظ الجلالة علم مشقق. القول الثاني: - (ذهب أكثر العلماء إلى أن لفظ الجلالة علم للــــات المقدسـة غيــر

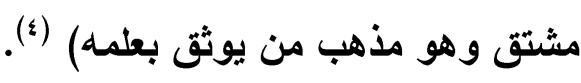

(1) مجمع البيان لعلوم القرآن - للأمام ابن علي الفضل بن الحسين الطبرسي ( / ( ؟) جا دار القرآن للطباعة و النثر .

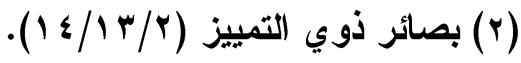

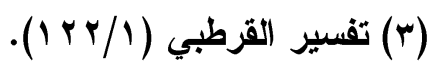

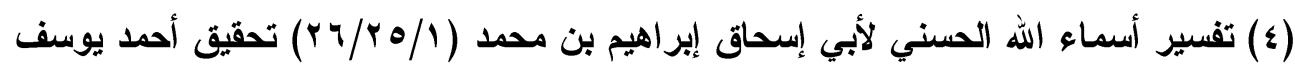

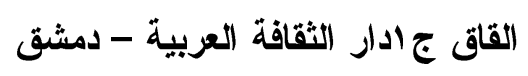




\section{قال الشيخ هبد الدين الفيروز أبادي:}

(وقال الاكثرون علم مرتجل غير مشتق وعزي للأكثريين من الفقهــاء والأصــوليين،

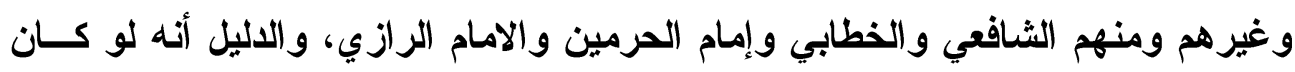

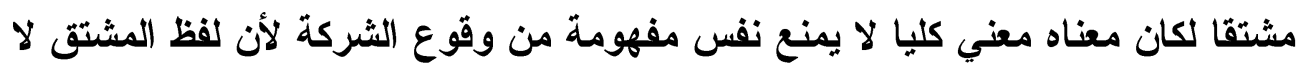

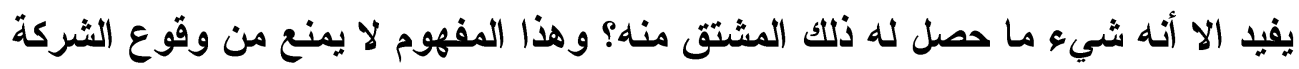

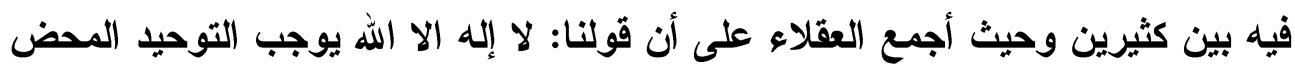

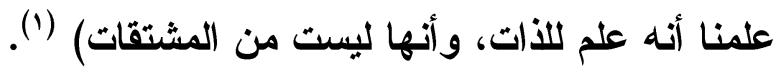

(ورجح الكثير من العلماء أنه(الله) هو اسم الله الأعظم) (†).

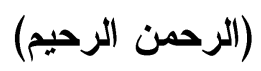

(الرحمن: اسم خاص بالله، والرحيم: يطلق عليه وعلى غيره فان قيـل : فعــي هـــا الرحمن أعظم. فلم ذكر الأدنى بعد ذكر الأعلى واله

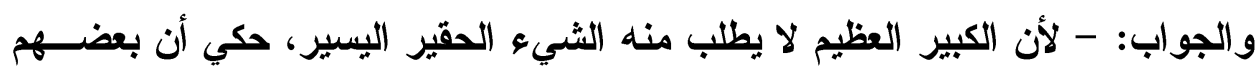

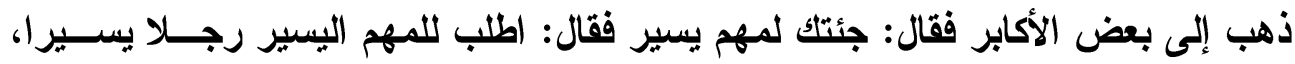

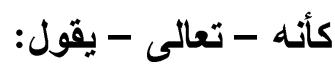

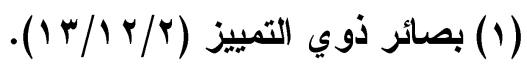

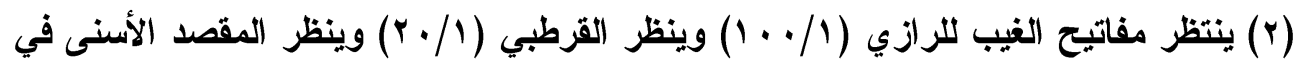

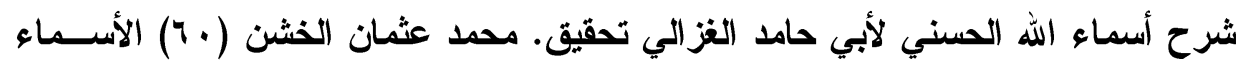

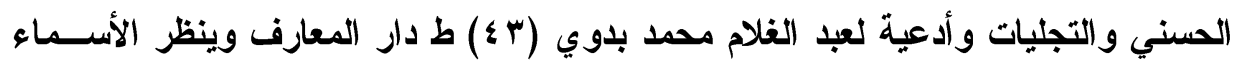

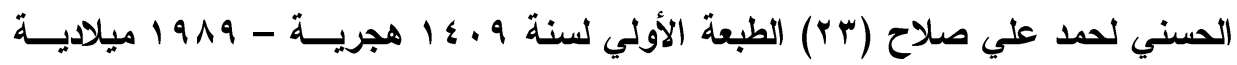
وينظر بصائر ذوي التمييز (Y/ ا (T). 
لو اقتصرت على ذكر الرحمن لاحتشت عني ولتعذر عليك سؤال الامور اليسبيرة، ولكـن

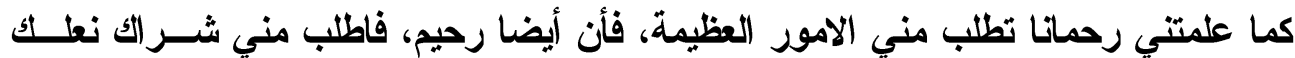
وملح قدرك، كما قال - تعالى - لموسى: (با موسي سلني عن ملح قدرك وعلف شاتلك) (').

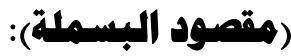

(ومن مقصود البسملة يقول ابن جرير - أن الله أدب نبيه محما :-سبتعليمه تقديم ذكر أسمائه الحسني أمام جميع أفعاله، وتقدم إليه في وصفه بها قبل جميع مهماته، وجعـل ما أدبه به من ذلك وعلمه إياه منه لجميع خلقه سنه يسنون بها، وسبيلا يتبعونه عليها، في افتتاح أو ائل منطقهم وصدور رسائلهم وكتبهم وحاجاتهم، حتي أغنت دلالة ما ظهـر

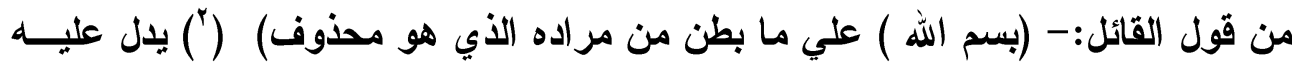

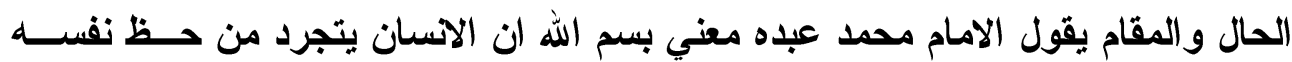

ويفعل بسم الله (r). (ل)

\section{الآية الثانية:-(الممد الله رب العالمين)}

(الحمد الله قال أبو جعفر ومعني الحمد: الثكر خالص الله جل ثناؤه دون سائر ما بعبد من دونه، ودون كل ما برأ من خلقه، بما أنعم على عباده من الـــعم التــي لا يحصـيـيها العدد، ولا يحيط بعددها غيره أحد، في تصحيح الآلات لطاعته، وتمكين جوارح أجسـام

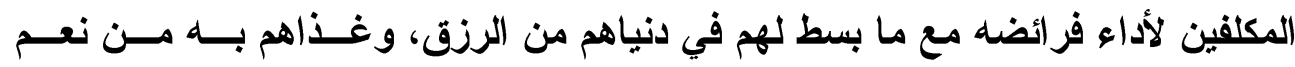

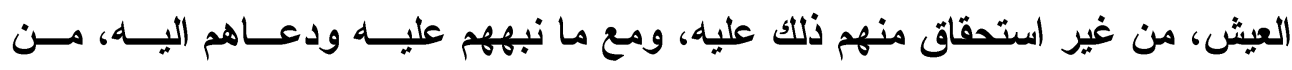

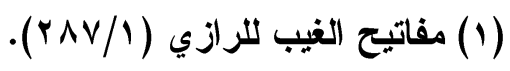

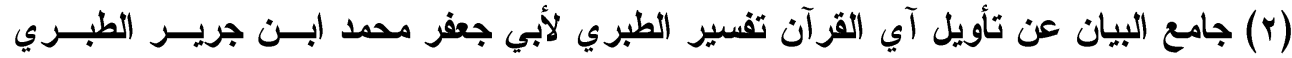

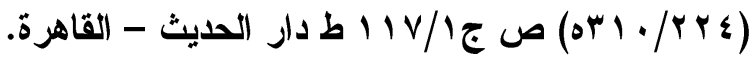

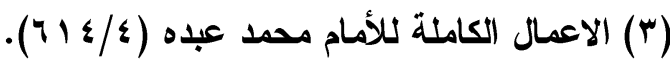


الأسباب المؤدية إلى دوام الخلود في دار المقام في النعيم المقيم - فلربنا الحمد. الحمــ

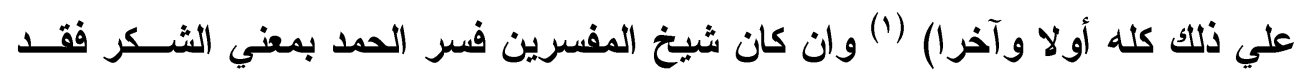

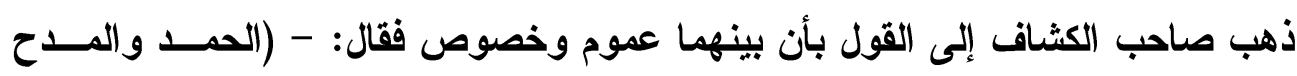

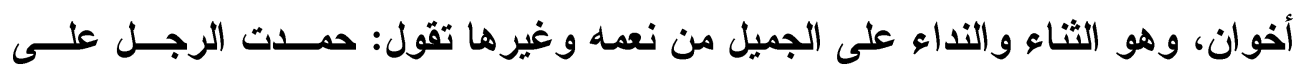
انعامه، وحمدته على حسبه وشجاعته). وأما الثكر فعلى النعمة خاصة وهو بالقلب و اللسان والجوارح قال: أفادتكم النعماء مني ثلاثة يلدي ولساني و الضمبر المحجبا والحمد باللسان وحده، فهو إحدى شعب الثكر، ومن قوله - علىه السلام: - "الحمد

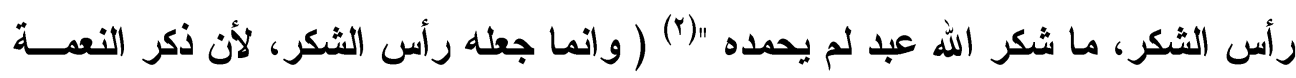

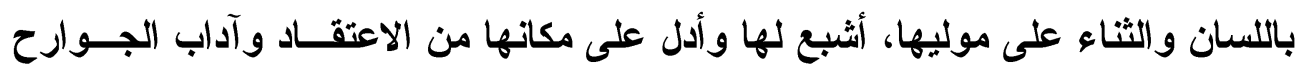
لخفاء عمل القب، وما في عمل الجوارح من الاحتمال، بخلاف عمل اللسان وهو النطق

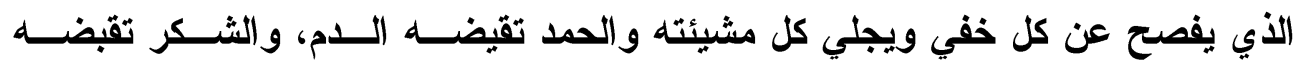

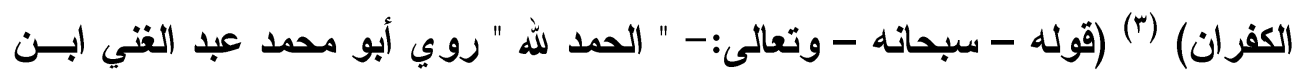

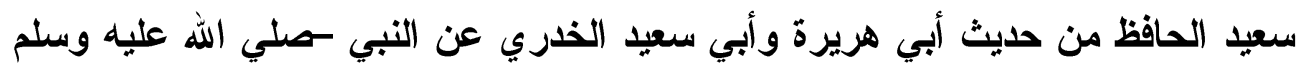

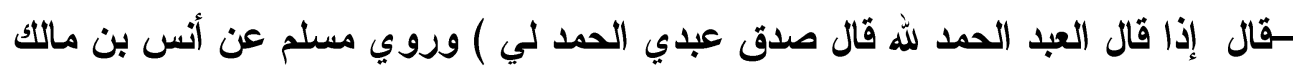

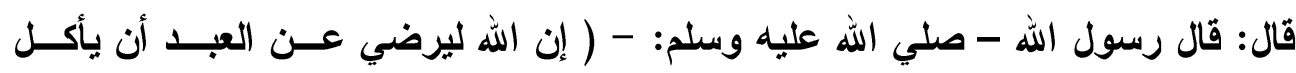

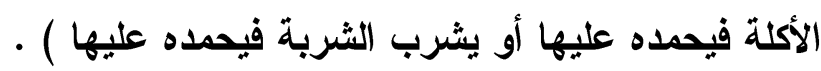

$$
\text { (1) (1) تفسير الطبري (9/1 (1) (1). }
$$

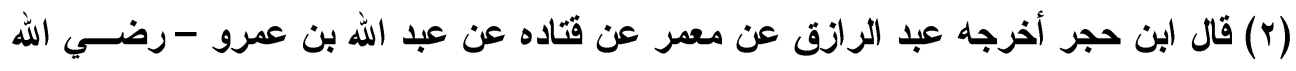

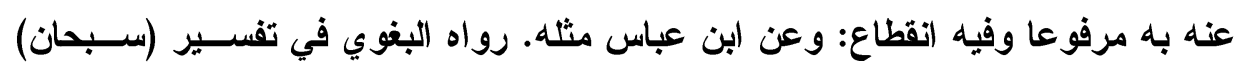
وفيه نصر بن حماد وهو ضعيف.

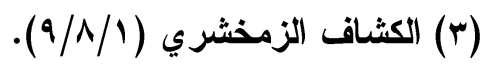


وقال الحسن): - ما من نعمة إلا والحمد لله أفضل منها) (1) وعن وجه الارتباط بـين

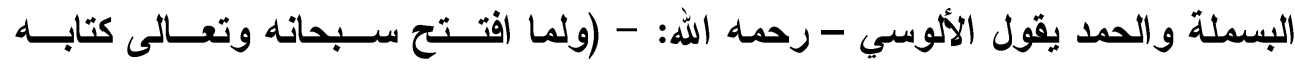

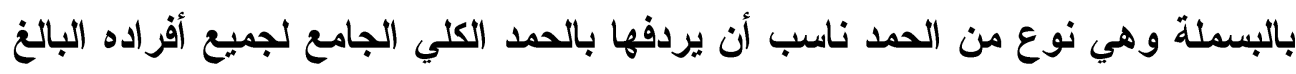

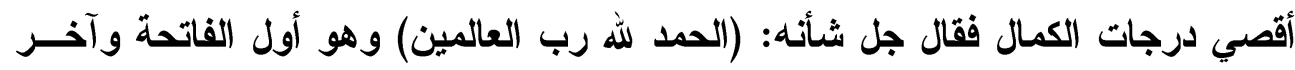

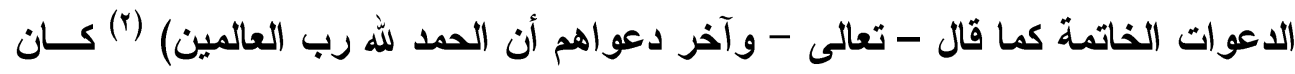

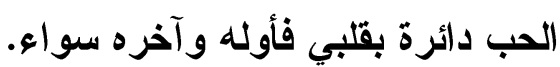

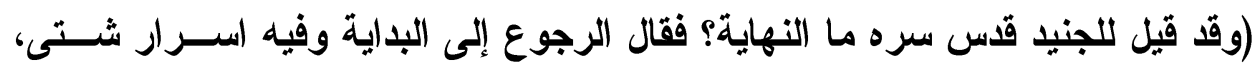

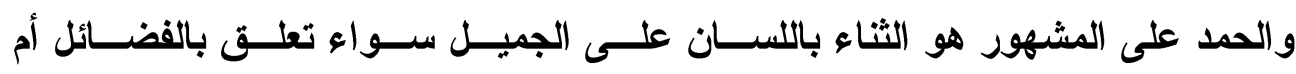

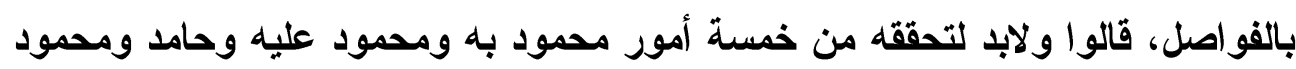
وما يدل على اتصاف المحمود بصفه) (r). يقول الإمام الرازي - رحمه الله (أنه - تعالى - لم يقل أحمد الله ولكن قال:" الحمد لله " وهذه العبارة الثانيــة أولـــى

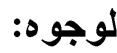

أحدها: أنه لو قال أحمد الله أفاد ذلك أنه كان القائل قادرا على حمده أمسـا لبــا قــال

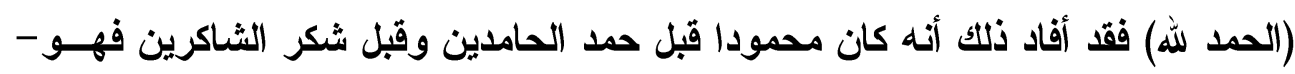
تعالى - محمود من الأزل الى الأبد بحمده القديم وكلامه القديم.

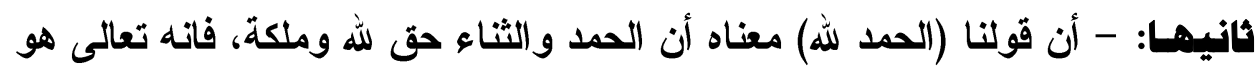

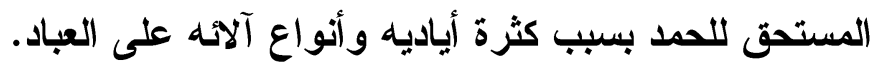

$$
\begin{aligned}
& \text { (1) تفسير القرطبي (101/1). } \\
& \text { (Y) سورة يونس (·) (1). } \\
& \text { (T) روح للمعاني للألوسي (T/ (T/ (T) (T). }
\end{aligned}
$$


ثالثها: - أنه لو حمد الله لكان قد حمد لكن لا حدا يليق به، وأما إذا قال (الحمد لله) فكأنه قال من أنا حتى أحمده؟ لكنه محمود بجميع حمد الحامدين. رابعهـا: - ان الحمد عبارة عن صفة القلب وهي اعتقاد كون ذلك المحمود متفضـلا

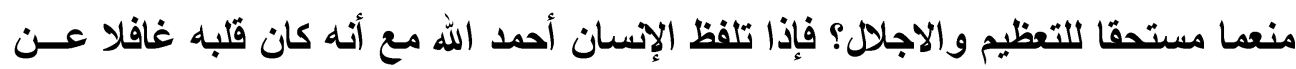

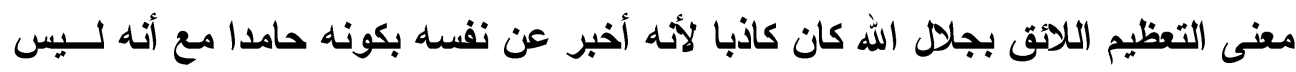

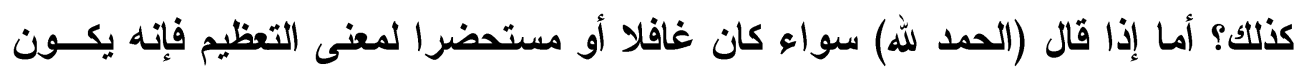

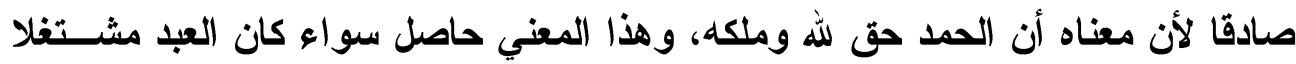

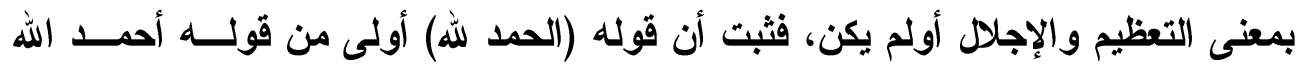

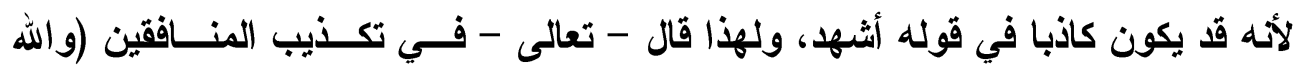

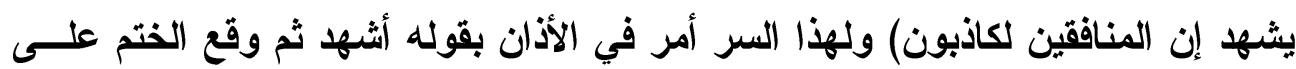
قوله لا إله إلا الله) (1).

(رب العالمين) الرب: المالك ومنه قول صفوان لأبى سفيان: لأن يريني رجل من قريش أحب الى من

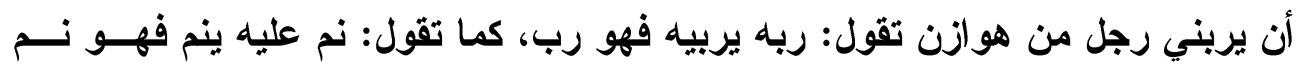

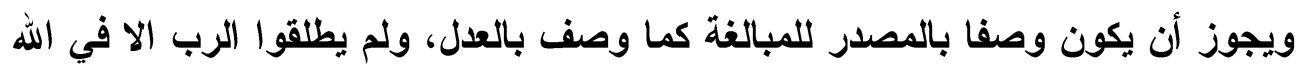

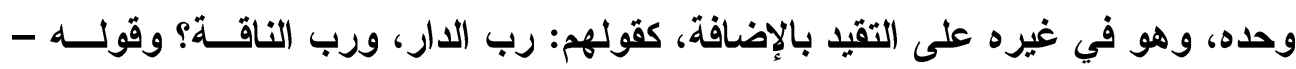

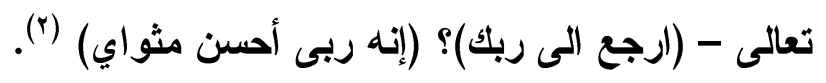

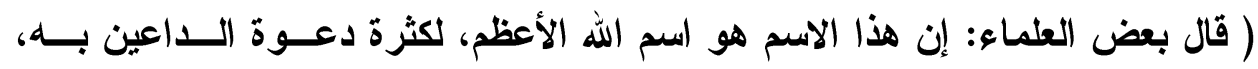

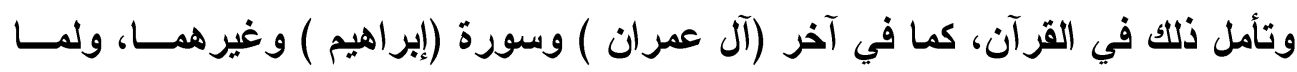

$$
\begin{aligned}
& \text { (1) مفتاح الغيب (Y (Y (Y (1). } \\
& \text { (r) الكثاف (1/1) (1/). }
\end{aligned}
$$




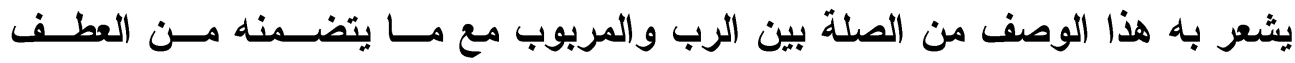
والرحمة والافتقار في كل حال واختلف في اثثتقاقه، فقيل: إنه مثتق من التربية، فالله

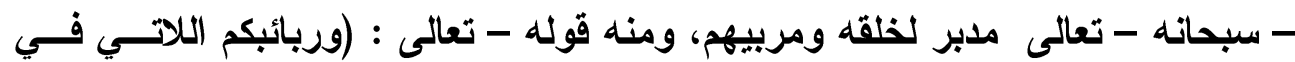

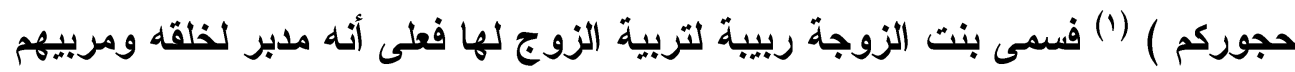

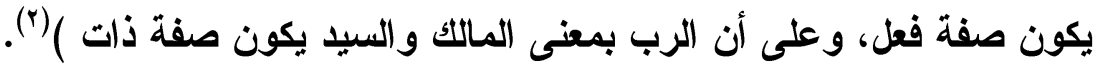
(واعلم أن تربيته تعالى - مخالفة لتربية غيره؟ وبيانه من وجوه: الأول: - ما ذكرناه أنه- تعالى - يربى عبيده لا لغرض نفسه بل لغرضهم وغيـرهم يريون لغرض أنفسهم لا لغرض غيرهم.

الثاني: -أن غيره إذا ربى فبقلر تلك التربية يظهر النقصان وفي خزائنه وفي مالــهـ

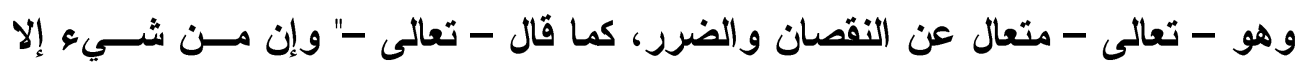
عندنا خزائنه وما ننزله إلا بقدر معلوم ".

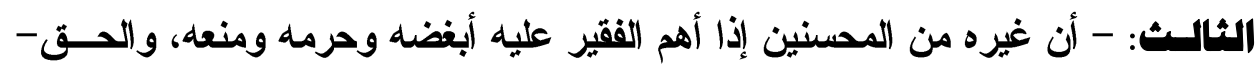

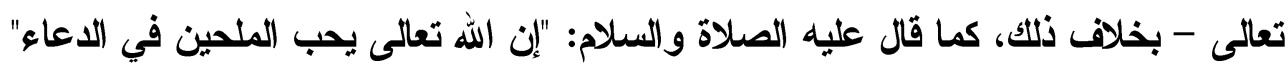
الرابه: -أن غيره من المحسنين ما لم يطلب منه الإحسان لم يعط. أما الحق - تعالى - فإنه يعطي قبل السؤال، ترى أنه رباك حال ما كنت جنينـا فـــي

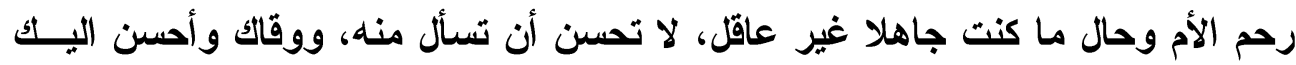

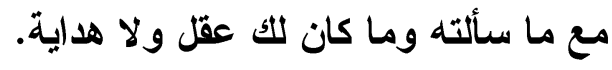

$$
\begin{aligned}
& \text { (1) سورة النساء (YT) (YT). }
\end{aligned}
$$

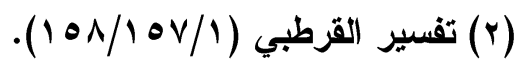




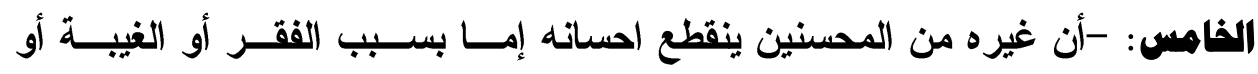
الموت، والحق -تعالى - لا ينقطع إحسانه البتة.

السـادس: -أن غيره من المحسنين يختص إحساته بقوم دون قوم ولا يمكنه التعميم أبــا

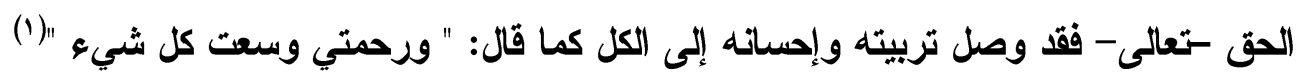

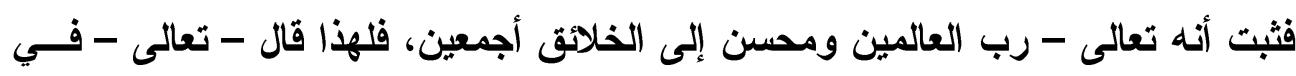

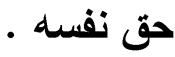

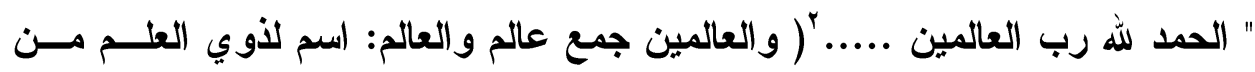

الملايكة والثقلين وقيل: كل ما علم به الخالق من الأجسام والأعراض فإِ قلت

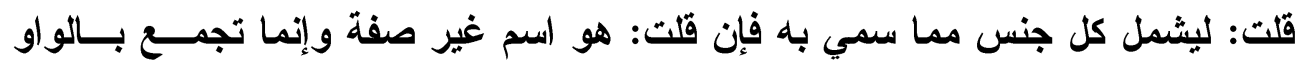

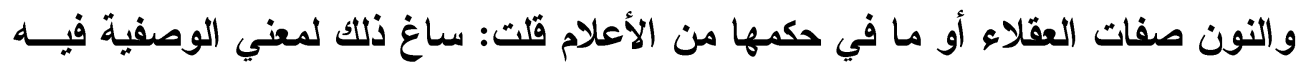
وهي الدلالة على معني العلم) (").

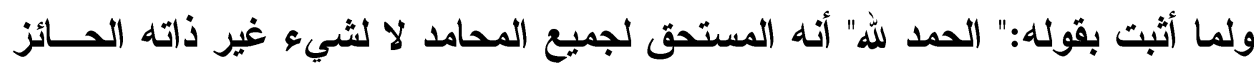

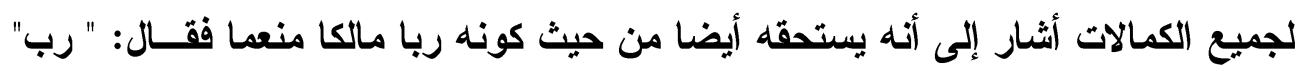

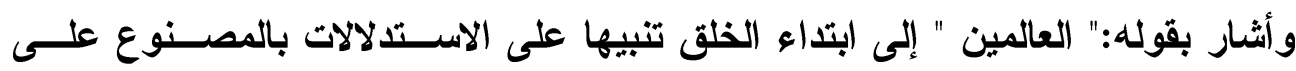
الصانع وبالبداءة. مقاصد هذه الآية: - "الحمد لله رب العالمين" ا-توحيد الألوهية والريوبية حيث جعلت الحمد كله لله فالنعم منــهـه جميعـا والظــق و الأمر وأثبتت ربوبيته للعالمين.

$$
\begin{aligned}
& \text { (1) الأعر اف (107) (1). }
\end{aligned}
$$

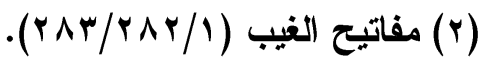

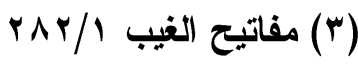


rاساقت الآية بذكر العالمين استدلالا بالصنعة على الصانع وفي كل شيء له آية تدل

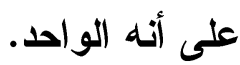

r-مجئ وصف الربوبية بعد الحمد لقصد بيان استحقاقه سبحانه للمحامد كلها حيــث

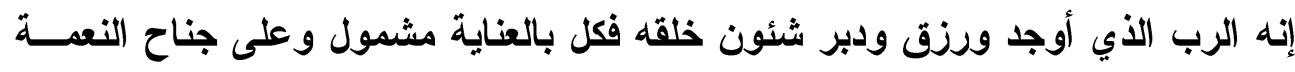

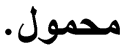

\section{الآية الثالثة: (الرحمن الرحيم)}

(يذكر ابن جرير - رحمه الله -استلال القائلين إن البسملة ليست آية مسن الفاتحسة

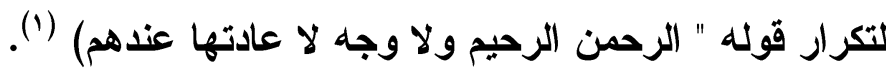

وقال الامام الألوسي: (واستدل بعض ساداتتا بتكرارهما على أن البسملة ليست آيسـة من الفاتحة وليس بالقوي لأن التكرار لفائدة، فذكرهما في البسملة تعليل للابتاء باسما لأنها عز شأنه، وذكرهما هنا تعليل لاستحقاقه - تعالى الحمد) (†).

(الرحمن اسم خاص بالله، والرحيم: يطلق عليه وعلى غيره فإن قيـل: فعلـى هـــا

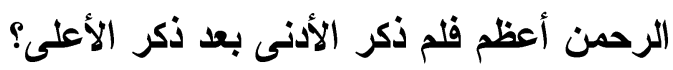

والجواب: لأن الكبير العظيم لا يطلب منه الثيء الحقير اليسير، حكـي أن بعضــهم ذهب إلى بعض الأكابر فقال: جئتك لمهم يسير فقال: اطلب المهم اليسير رجــلا يسـيرا،

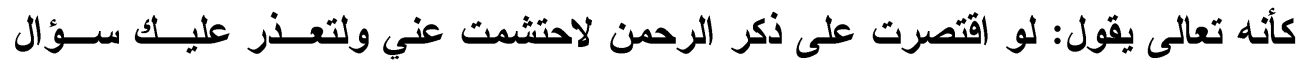

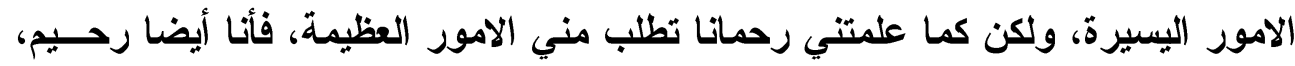

$$
\begin{aligned}
& \text { (1) تفسير الطبري (1) (1)/11). }
\end{aligned}
$$

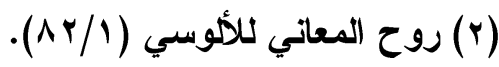


فاطلب مني شرالك نعلك وملح قدرك كما قال تعالى لموسى: "يا موسى سلني عــن مـــح قرك و وعلف شاتك ".

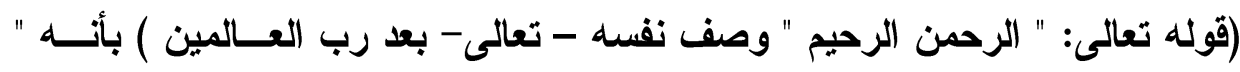

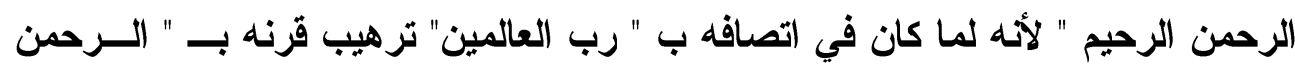

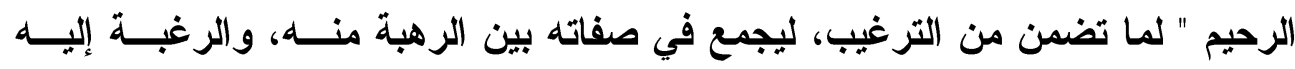

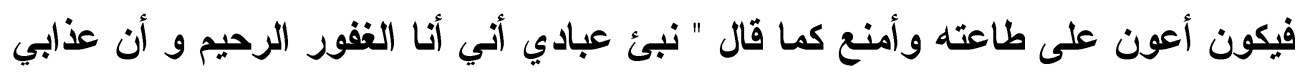

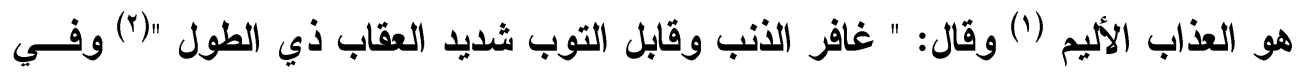

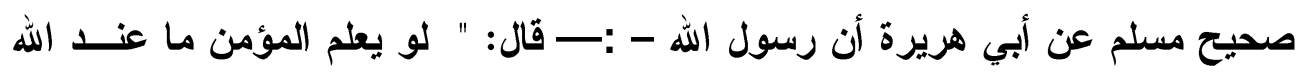

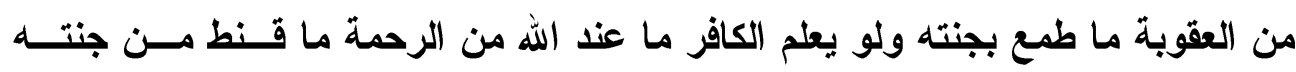

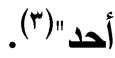

(ولما كانت مرتبة الربوبية لا تستجمع الصلاح إلا بالرحمة اتبع ذلك بصفتي " الرحمن

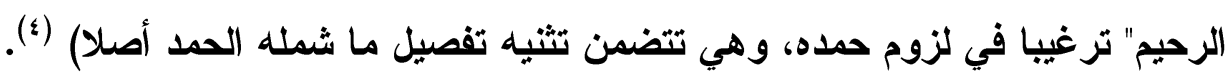

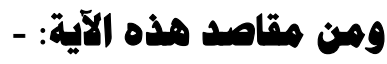
/ / دلت على الإيمان بالأسماء و الصفات بلفظها ومقصــود إيــراد هـــين الاســمين

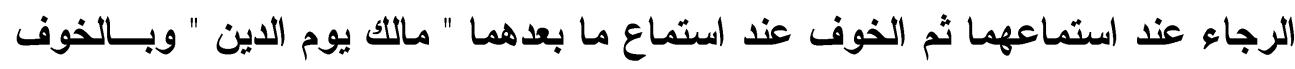

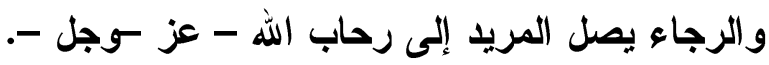

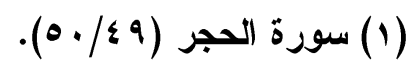

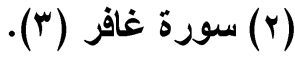

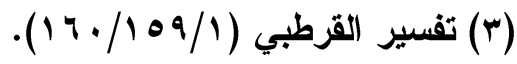

$$
\begin{aligned}
& \text { (ع) نظم الدرر (1/ (1) (1). }
\end{aligned}
$$




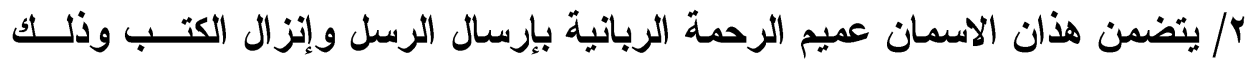
رحمه من الله بعباده كي ينجو من عذابه.

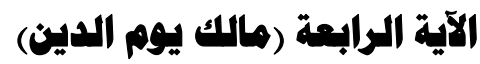

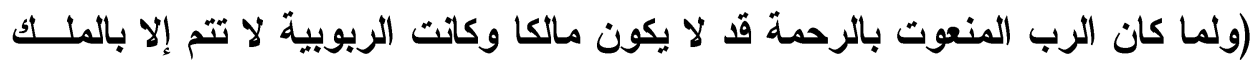

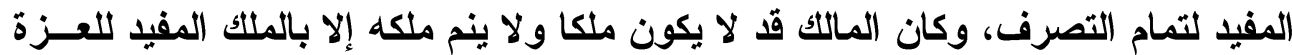

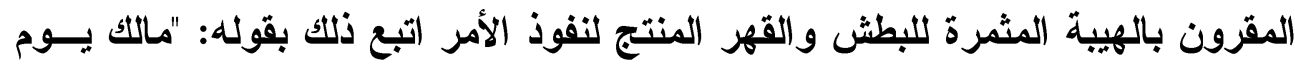
الاين " ترهيبا من سطو ات مجده) ('). (وهذه الاوصاف التي أجريت على الله سبحانه - من كونه ربا مالكا للعالمين لا يخرج

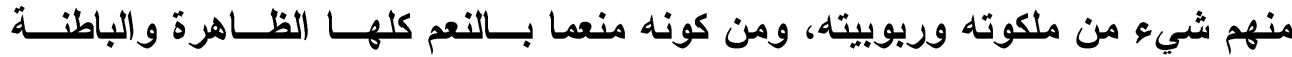
والجلائل والدقائق، ومن كونه مالكا للأمر كله في العاقبة يوم الثواب و العقاب بعد الدالادة على اختصاص الحمد به وأنه به حقيق في قوله الحمد الله - دليل على أن من كانت هذه

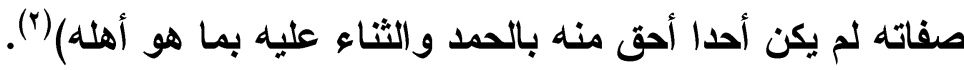

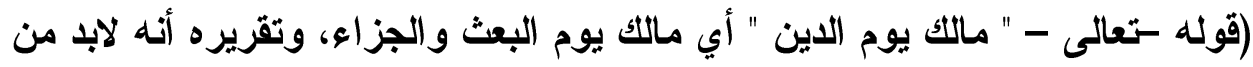

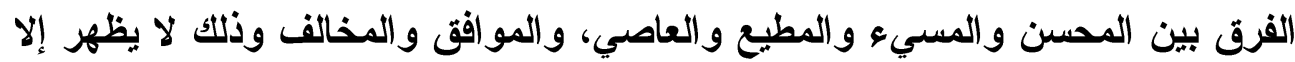

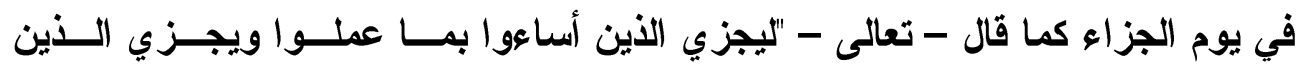

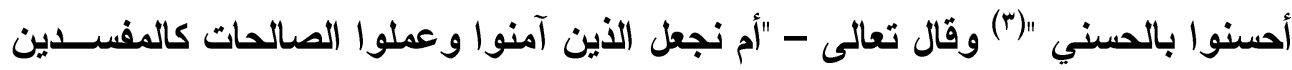

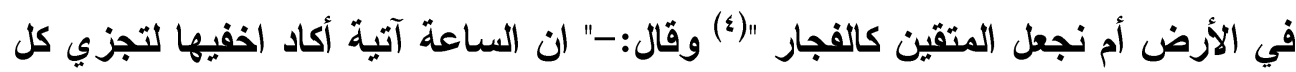

$$
\begin{aligned}
& \text { (1) نظم الارر (1/ (1) ). }
\end{aligned}
$$

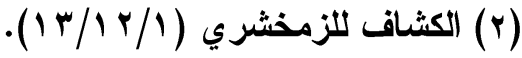

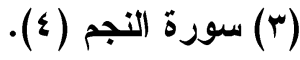

$$
\begin{aligned}
& \text { ( ) سورة ص (r^). }
\end{aligned}
$$


نفس بما تسعي "(1) واعلم أن من سلط الظالم على المظلوم ثم إنه لا ينتقم منه فذإك إما

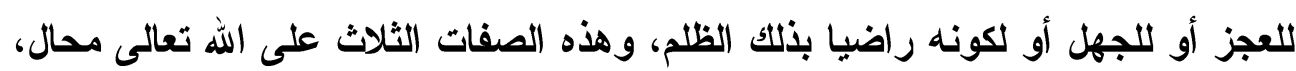
فوجب أن يقتص للمظلومين من الظالمين، ولما لم يحصل على هذا الاتتقام في دار الدنيا

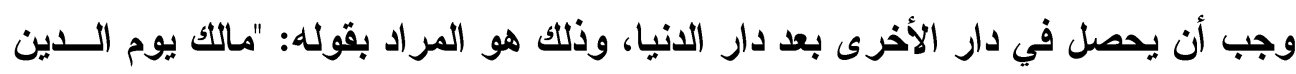

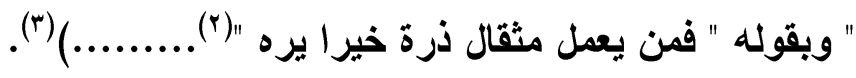

$$
\begin{aligned}
& \text { (يقول الامام القرطبي: - }
\end{aligned}
$$

(لا يجوز أن يتسمى أحد بهذا الاسم ولا يدعي بــه إلا الله تعــالى، وروى البخــاري

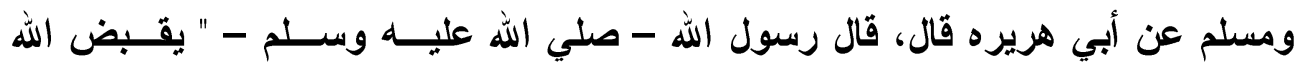
الارض يوم القيامة ويطوي السماء بيمينه ثم يقول أنا الملك أين ملوك الأرض اله وعنه أيضا عن النبي - صلي الله عليه وسلم -قال: " إن أخنع اسم عنــــ الله رجـل تسمي ملك الأملاك - زاد مسلم - لا مالك إلا الله - عز وجل - " قال سفيان: " مثلل: شاهان شاه وقال أحمد بن حنبل: سألت أبا عمر الثــيباني عـن الهن أخنع، فقال: أوضع " وعنه قال، قال رسول الله - صلي الله عليه وسلم - أغـيظ رجـلـ

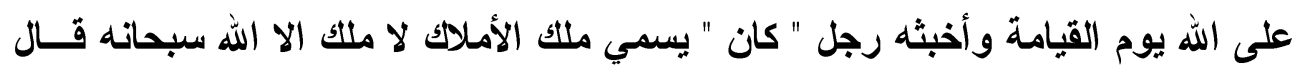

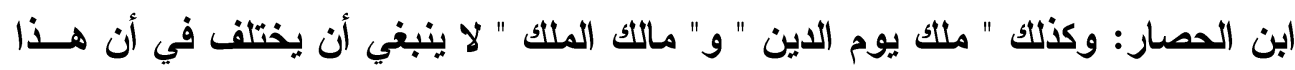
محرم على الجميع المخلوقين كتحريم ملك الأملاك سواء، وأما الوصف بمالك وملكك: ............

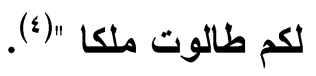

$$
\begin{aligned}
& \text { (1) سورة طه (10). }
\end{aligned}
$$

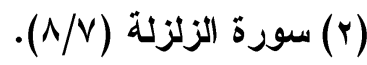

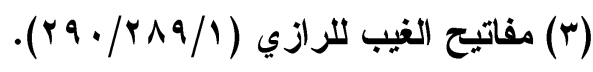

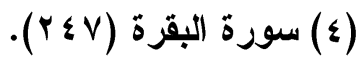


وقال صلي الله عليه وسلم-: "تاس من أمتي عرضو على غزاة في سبيل الله يركبون

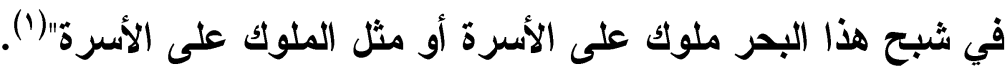

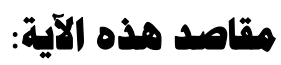

مع أن هذه الآية كلماتها معدودة إلا أنها حوت مقاصد عديدة منها: اــ أنها قد أثشارت مع سابقها إلى أوصاف الله وجلالة وكماله وملكه الدائم وانفراده بالملك يوم الجزاء.

rـ أثبتت البعث والجزاء وهو متطمئن لإثبات الوعد و الوعيد.

rــ ورود هذه الآية قبل ذكر العبادة والاستعانة له مقصد جليل وهو أن المتعبد يضع

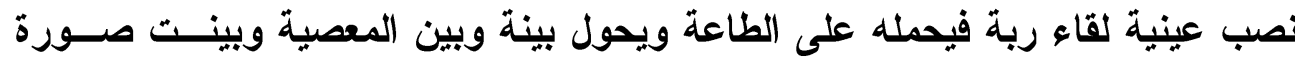
الفرقان أن الذي حمل الجاحدين على التكذيب والعناد عدم الايمان بيـوم الــدين قــال -

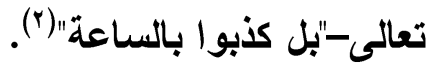

؛ـ هي إثـارة إلى السمعيات من أهو ال القيامة والصراط و الميزان والحساب والجنة و النار لكون ذلك كله في هذا اليوم العظيم الآية الخامسة "إياك نعبد وإياك نستعين"

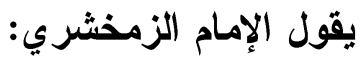

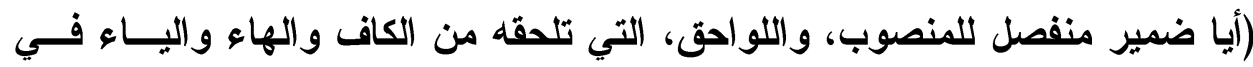
قوللك إياك، وإياه، لبيان الخطاب والغيبة والتكلم، ولا محل لها من الإعراب، كما لا محل للفهل

$$
\begin{aligned}
& \text { (1) تفسير القرطبي (19/1 (1 ). } \\
& \text { (Y) سورة القرقان (II). }
\end{aligned}
$$


للكاف في أرأيتك، وليست بأسماء مضمرة، وهو مذهب الأخفش وعليه المحققون، وأما

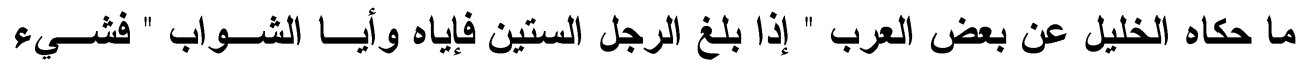
شاذ لا يعول عليه، وتقديم المفعول لقصد الاختصاص ، كقوله تعـالى: قـلـل أفغيــــ الله

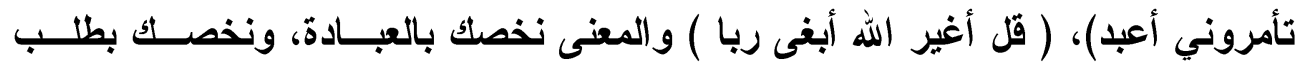

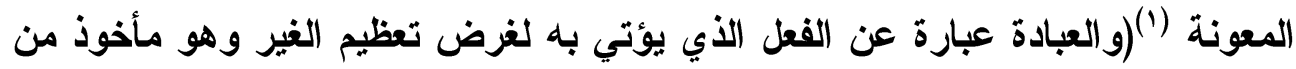

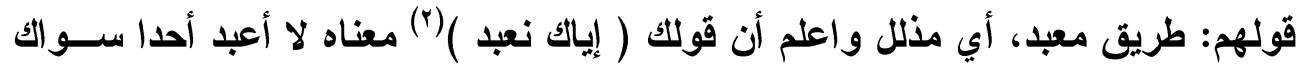
والأى يلز على هذا الحصر وجوه:

الوجهه الأول: - أن العبادة عبارة عن نهاية التعظيم، وهى لا تليق إلا بمن صدر عنه غاية الإنعام، وأعظم وجوه الإنعام الحياة التي تفيل المكنة من الانتفاع وخلق المنتفع به،

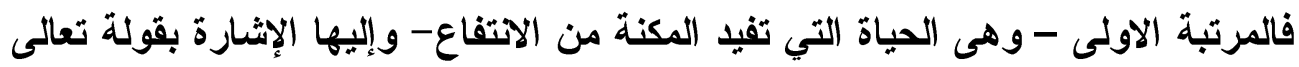

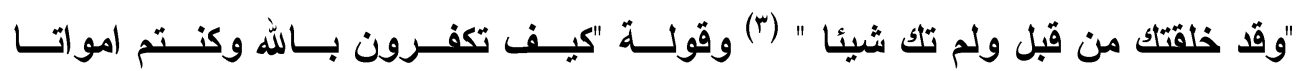

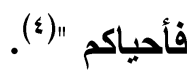
والمرتبة الثانية: هي خلق المنتفع به - وإليها الاثارة بقوله تعالى " وهو الذي خلق لكم ما في الأرض جميعا "(ه). ولما كاتت المصالح الحاصلة في هذا العالم السفلي إنما نتظظم بالحركات الفلكية علـى

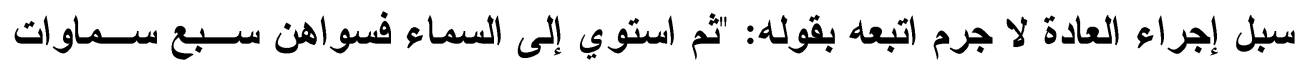

$$
\begin{aligned}
& \text { (1) الكثاف (1/ (1 1). } \\
& \text { (r) الفاتحة (†) (r) }
\end{aligned}
$$

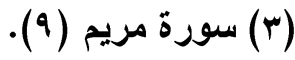

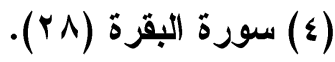

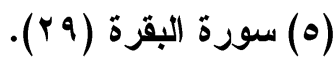




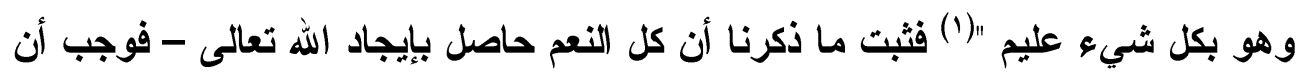

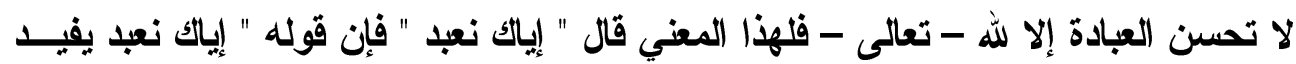

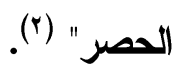

(و العبادة أعلي مراتب الخضوع ولا يجوز شرعا ولا عقلا فعلها إلا لله - تعالى - لأنه

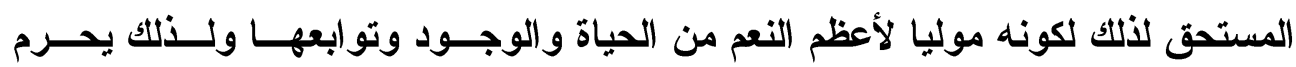

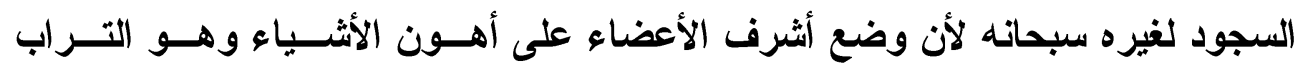

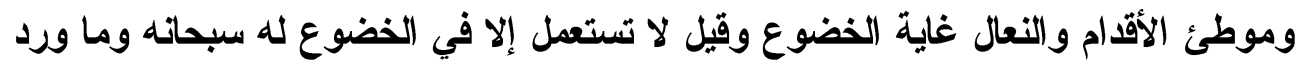

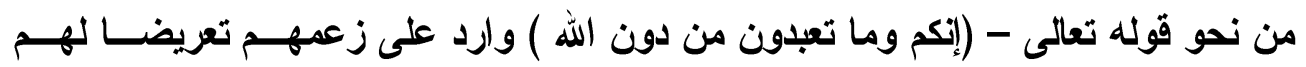

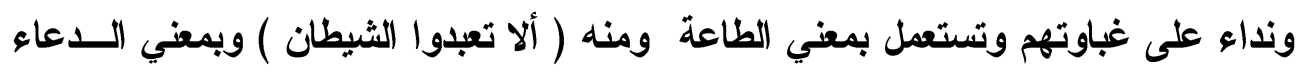

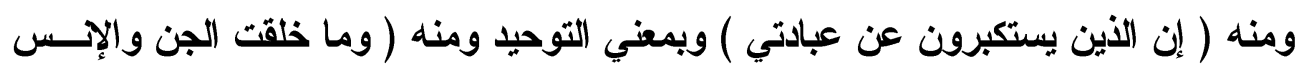

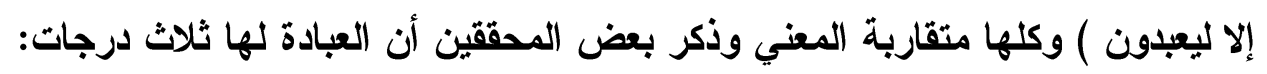
الأله إما أن يعبد الله - تعالى - رغبة في ثوابه أو رهبة في عقابه ويختص باستم

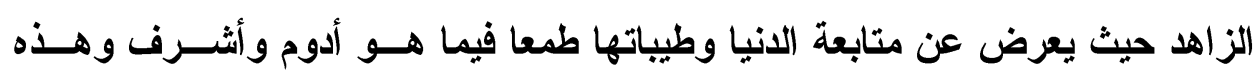

$$
\text { مرتبة نازيله عند أهل الله - تعالى - وتسمي عبادة. }
$$

r. و إما أن يعبد الله تعالى - تثرف بعبادته أو لقبوله لتكاليفه أو بالاتتســاب إليـهـ

$$
\text { و هذه مرتبة متوسطة وتسمي بالعبودية. }
$$

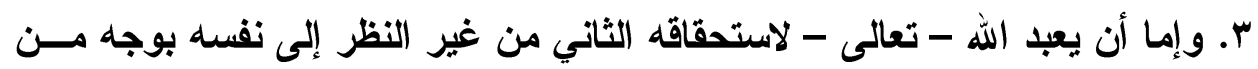
الوجوه وهو لا يقتضيه إلا الخضوع والذلة وهذه أعلي الارجات وتسمي بالعبودة و إليــهـ

$$
\text { (1) - (1) سورة البقرة (Y) (Y). }
$$

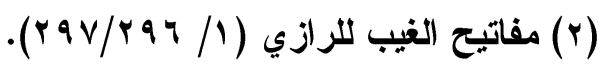


الاشارة بقول المصلي (صلى الله - تعالى - فإنه لو قال أصلي لثوابه -تعالى - مـثُلا أو

للتشريف بعبادته فسدت صلاته) (1)

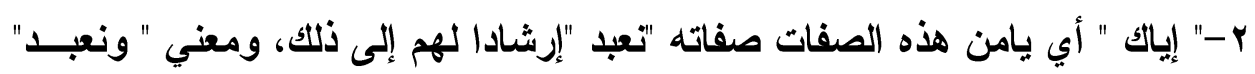

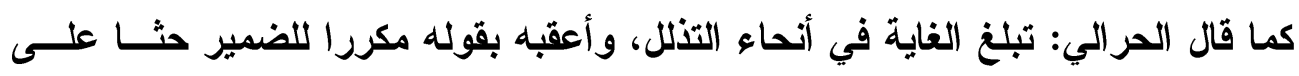

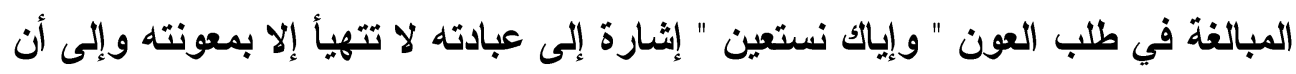

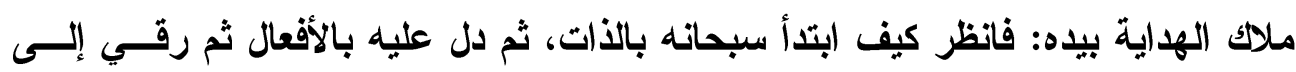

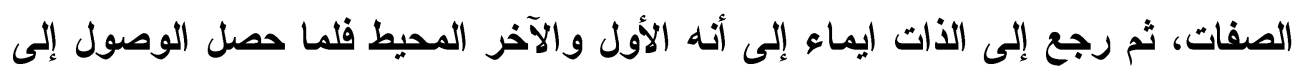

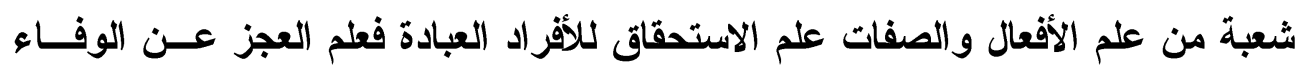

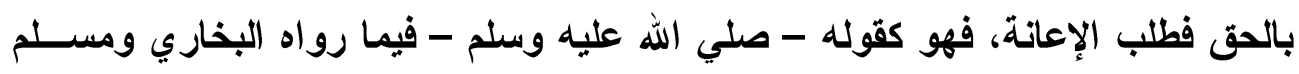

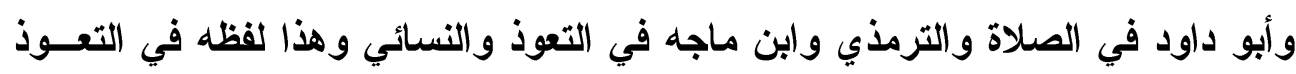
عن عائشة - رضي الله عنهما: "أعوذ بعفوك من عقويتك وبرضاك من سخطك، ويك منك ". ثم أتبعه فيما زاد من النسائي الاعتراف بالعجز في قوله:" لا أحصي ثناء عليك أنســـ

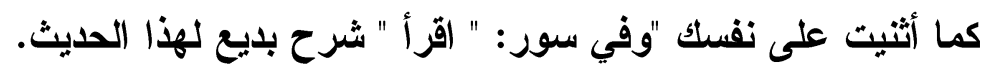
قال العرالي: وهذه الآيات أي هذه وما بعدها مما جاء كلام الله فيه جاريا على لســـان

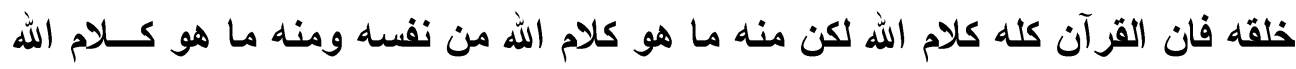

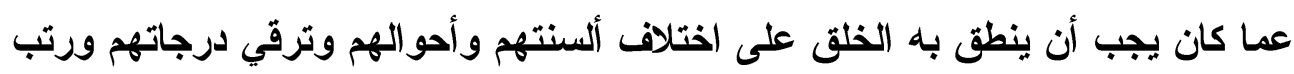

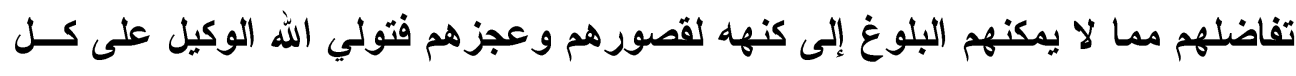

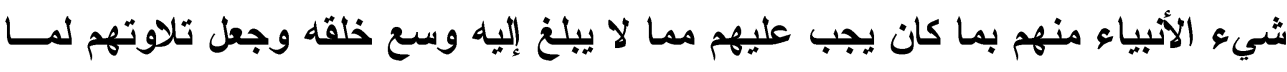

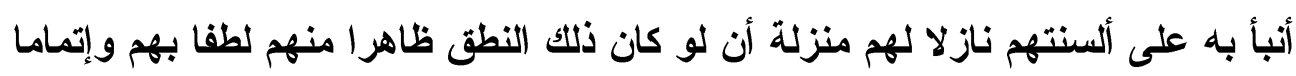

(1) روح المعاني للألوسي (1/Av/A ). 
للنعمة عليهم، لأنه تعالى وكلهم في ذلك إلى أنفسهم لم يأتوا بثيء تصلح به أحسو الهم

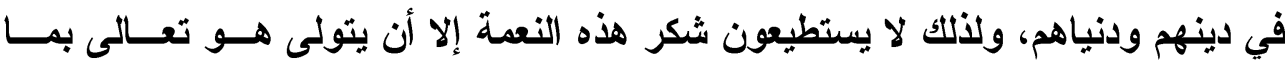

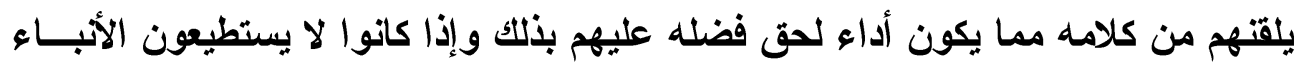
عن أنفسه بما يجب عليهز من حق ربهر فكيف بما يكون نبأ عن تحميد الله وتمجيــده، فإذا ليس لهم وصلة التلاوة كلامه العلي بفهم كان ذلك أو بغير فهم، وتلك هي صــلاتهم

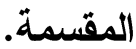

وفي قوله (" نعبد " بنون الاستتباع اشعار بأن الصلاة بنيت على الاجتماع) (1). (ولقائل أن يقول: قوله "الحمد الله رب العالمين * الرحمن الرحيم * مالكك يوم الدين "

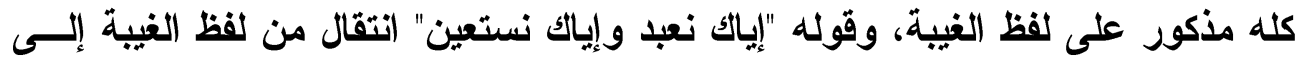
لفظ الخطاب، فما الفائدة منه قلنا فيه وجوه: الأول: أن المصلي كان أجنبيا عند الثروع في الصلاة، فلا جرم أثني على الله بألفــاط

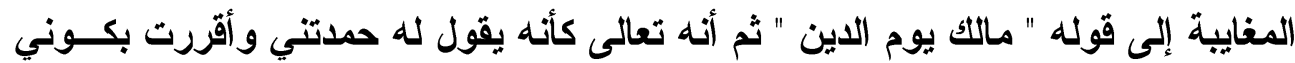

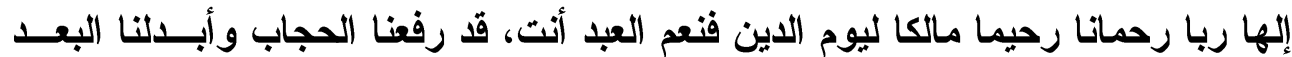

$$
\text { بالقرب فتكلم بالمخاطبة. }
$$

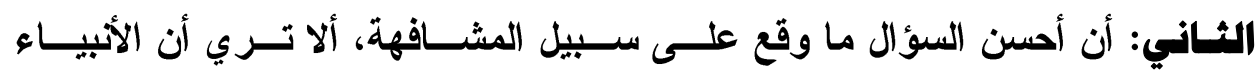

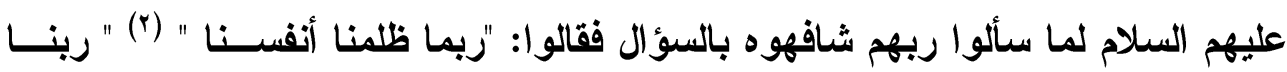

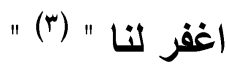

$$
\begin{aligned}
& \text { (1) نظم الارر (1 (1 ) (1 ). }
\end{aligned}
$$

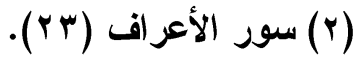

$$
\begin{aligned}
& \text { (r) سورة الحشر (· (1). }
\end{aligned}
$$


رب هب لي " (1)" رب أرني " (†) و العبب فيه أن الرد من الكريم على سبيل المشافهة

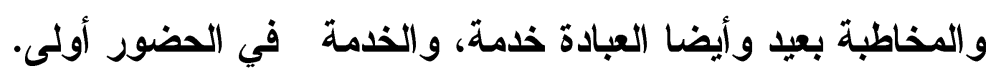

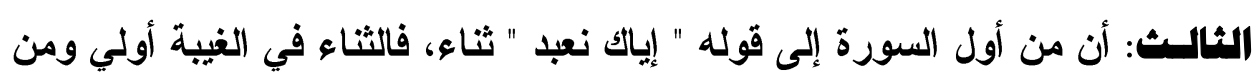

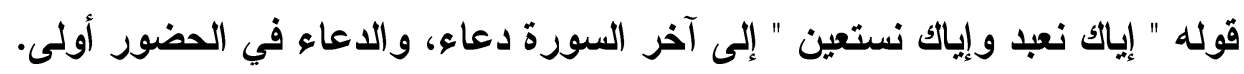

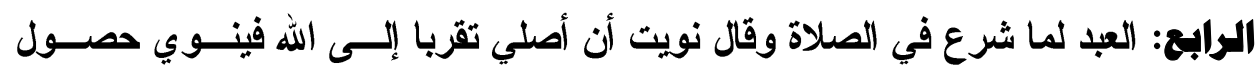

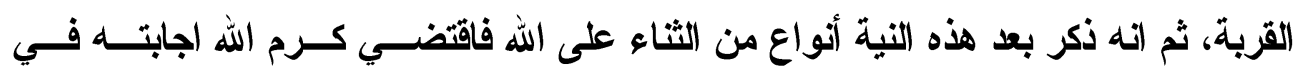

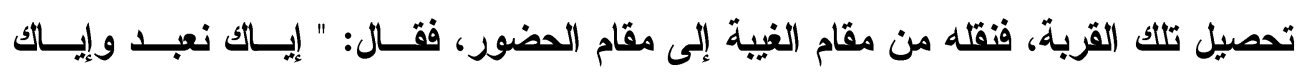
نستعين "( ن). ثم بين الفخر الرازي حكمة تقديم " إياك نعبد " على " إياك نستعين " مع أن الاستعانة

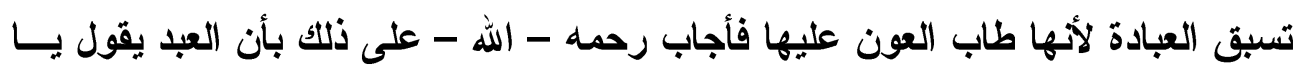

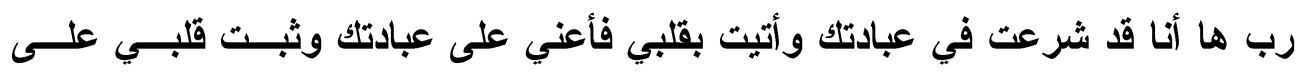

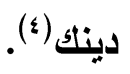

\section{مقاصد هذه الآية:}

1 - دلت هذه الآية على العبادة والاستعانة وجاء ذكرهما بعد ذكر يوم الــين لأههـ سبيل النجاح. ץ-افادت بطريقة الحصر حيث قدم المفعول على الفعل لقصد اخلاص العبادة وقصـر الاستعانة على الله وحده.

$$
\begin{aligned}
& \text { (1) سورة الشعراء (r) (ז). }
\end{aligned}
$$

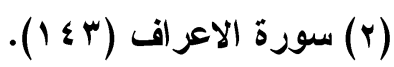

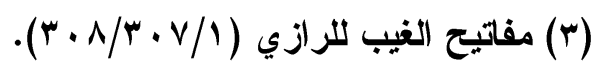

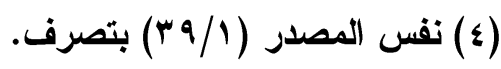


r--ما فيه من الخطاب يشير إلى مرتبة الاحسان.

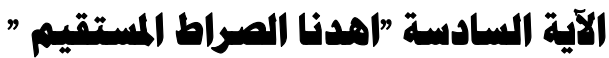

وصلة هذه الآية سبقوله - سبحانه - "إياك نعبد واياك نستعين "كمــا يقــول الامـــام

البقاعي - رحمه الله - (في الآية السابقة ندب إلى اعتقاد العجــز واستثــــار الافتقــار

والاعتصام بحوله وقوته، فاقتضي ذلك توجيه رغبات اليه بالسؤال فقال:" اهدنا الصراط اط الهيه

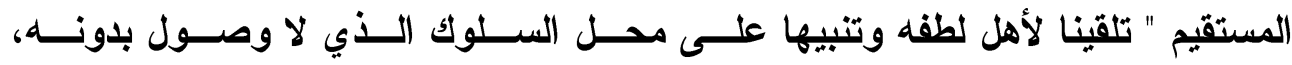

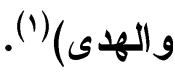

قال شيخ المفسرين: ومعني قوله "اهدنا الصراط المستقيم " في هذا الموضع عنــنـا:

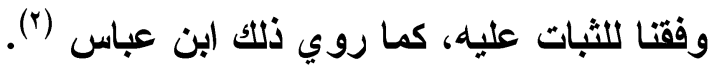
("اهدنا الصراط المستقيم "هدي اصلة ان يتعدى باليلام أو بإلى، كقوله -تعالى -"ان هذان

القر آن يهدي للتي هي اقوم"("َ).

"و إنك لتهاي إلى صراط مستقيم"(؛) فعومل معاملة -اختار -في -قولة تعالى: "واختار

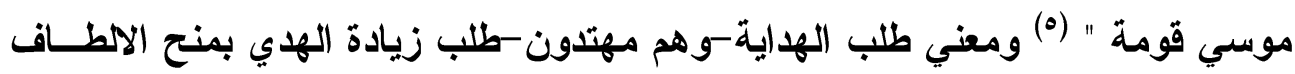

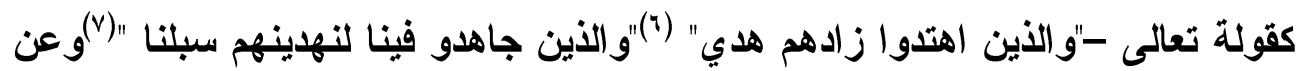
علي وأبي كرضي الله عنهما-: اهدنا ثبتنا وصيغة الامر والدعاء واحدة، لان كل واحـــ

منها طلب، وإنما يتفاوتان في الرتبة) (^).

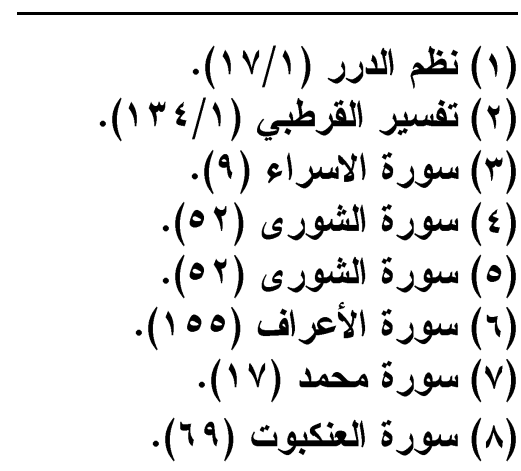


الصراط هو الطريق وذكر الأمـام القرطبي عن محمد بن الحنفية في قولــه عزوجـلـ: (اهدنا الصراط المستقيم، هو دين الله الأى لا يقبل من العباد غيره وقال عاصم الاحسـول

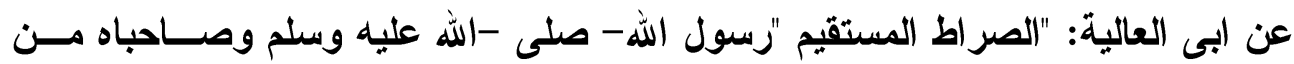
بعده قال عاصم الأحول فقلت للحسن: أن أبا العالية يقول: "الصر اط المسـتقيم " رســـول الله - صلى الله عليه وسلم - وصاحباه، قال صدق ونصـح) (') (وللمحققين فـي معنـي

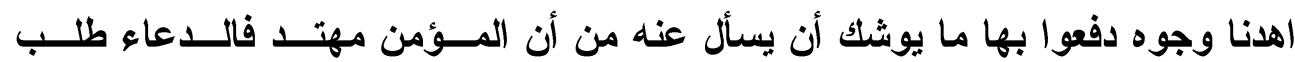
لتحصيل الحاصل. أحسدها: أن معناه ثبتنا على الدين كيلا تزلزلنا الشبهة وفى القرآن (ربنا لا تزغ قلوبنا بعد اذ هديتنا) وفى الحديث " اللهم يا مقلب القلوب ثبت قلوبنا على دينك. وثانيها: -أعطنا زيادة الهاى كما قال - تعالى - "والذين اهتدواز زادهم هلىى ". ثالثهـا: - أن الهاية الثواب كقوله - تعالى - "يهديهم ربهم بايمانهم " فالمعني اهدنا طريق الجنة ثوابا لنا وأيد بقوله - تعالى" الحمد لله الأي هدانا لهذا ". رابعما: (أن المراد دلنا على الحق في مستقبل ممرنا كما دللتنا عليه في ماضيه ولههم بعد أيضا بعض كلمات متقاربه غير هذا ولعله يغنيك عن الكل ما ذكره الفقير فتدبره ولا

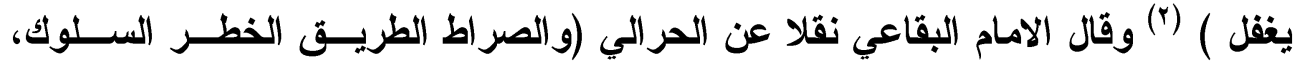
والآية من كلام الله - تعالى - " على لسان العلية من خلقه وجاء مكملا بكلمة "أل" لأســـه

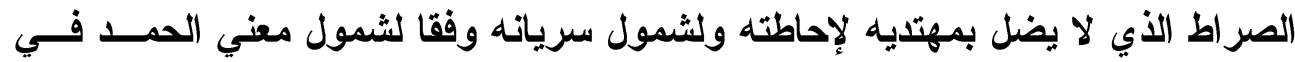

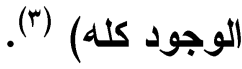

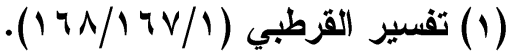

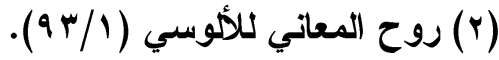

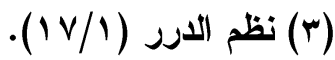




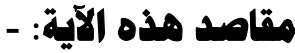

ا - الترغيب في دعاء الله عز وجل.

r - لزوم طريق الطاعة.

الآية السابعة "صراط الذين أنعمت عليهم غير المغضوب عليهم ولا الضالين "

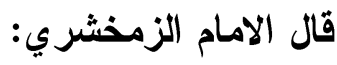

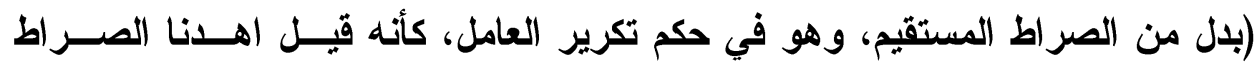

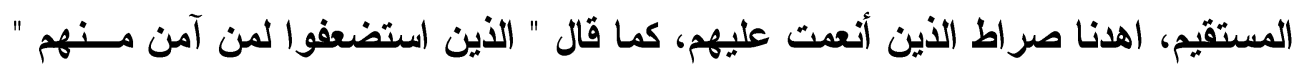
فان قلت ما فائدة البلد؟؟ وهلا قيل اهدنا صراط الذين أنعمت عليهم ؟ قلت: فائدته التوكيل

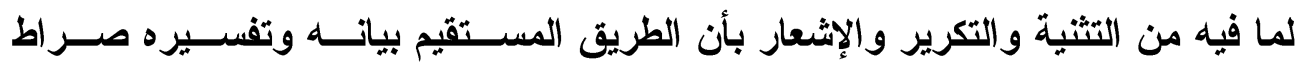

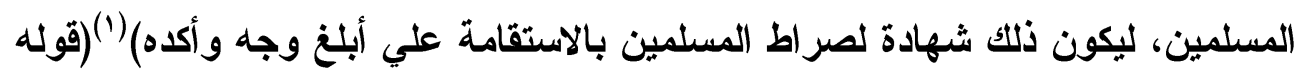

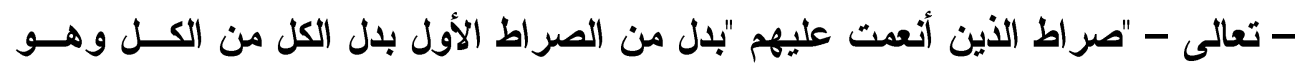

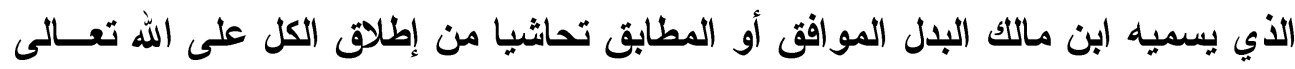

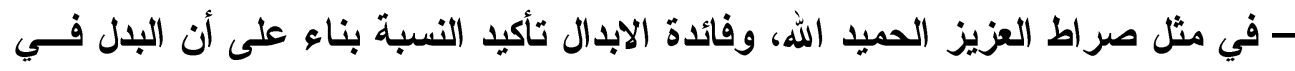
حكم تكرير العامل والإشعار بأن الصراط المستقيم بيانه وتفسيره صراط المسلمين فيكون

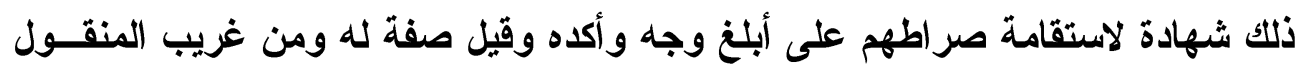

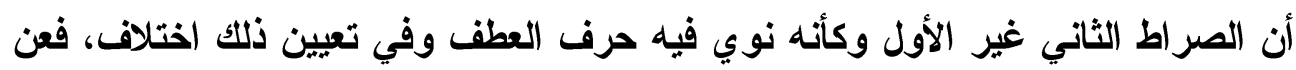

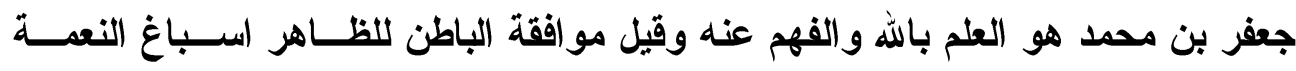
وقيل التزام الفرائض والسنن ولا يخفى (أن هذا القول خروج عن الصر اط المستقيم فــلا

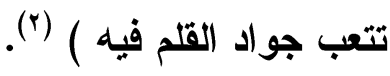

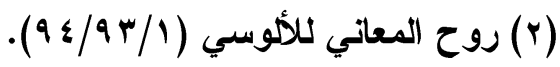


ويبين حبر الأمة - رضي الله عنه - المراد بالذين أنعم الله عليهم كمـــا أورده عنسهـ

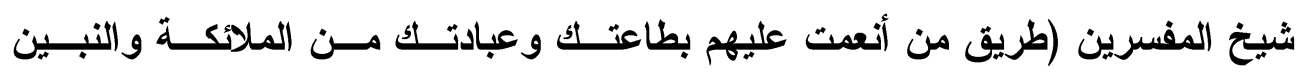

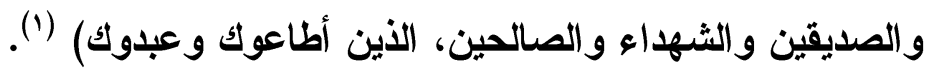

$$
\text { قوله - تعالى: (غير المغضوب عليهم ولا الضالين) }
$$

يقول فخر المفسرين: (المشهور أن المضضوب عليهم هم اليهود، لقوله - تعالى: "من

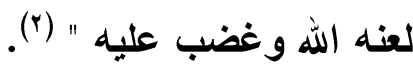

و الضالين: - هم النصارى لقوله - تعالى - " قد ضلو امن قبل وأضلوا كثيرا وضلوا

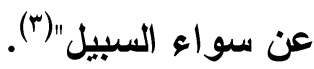

وقيل هذا ضعيف؟ لأن منكري الصانع و المشركين أخبث دينا من اليهـود و النصسـارى

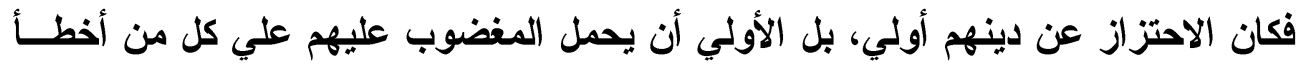

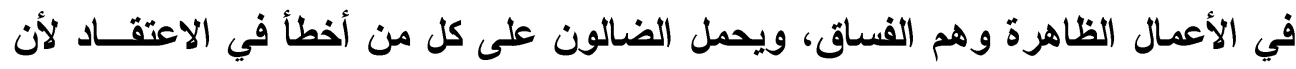

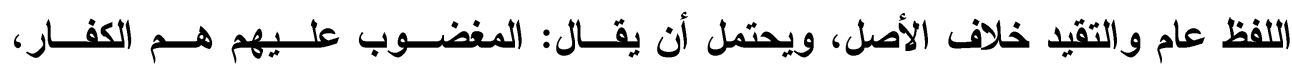
و الضالون هم المنافقون، وذلك لأنه تعالى - بدأ بذكر المؤمنين و الثناء عليهم في خمس التس

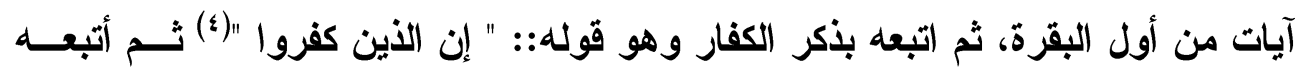

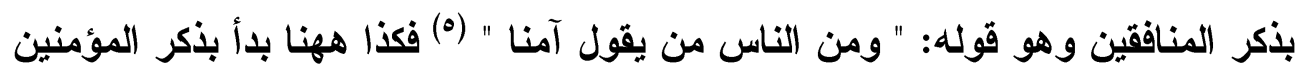

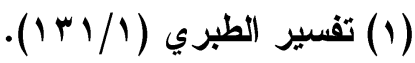

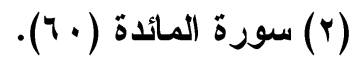

$$
\begin{aligned}
& \text { (Y) سورة المائدة (YV) (TV). } \\
& \text { (§) سورة البقرة (T). } \\
& \text { (•) سورة البقرة (^). }
\end{aligned}
$$


وهو قوله: "أنعت عليهم " ثم اتبعه بذكر الكفار وهو قوله "غير المغضوب عليهم " ثـــ

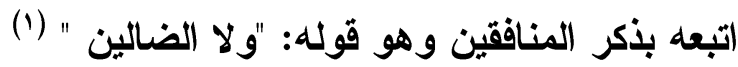

وذكر الإمام القرطبي أن المراد بالمغضوب عليهم والضالين عند الجمهور أنهم اليهود

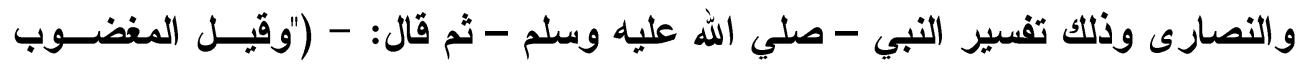

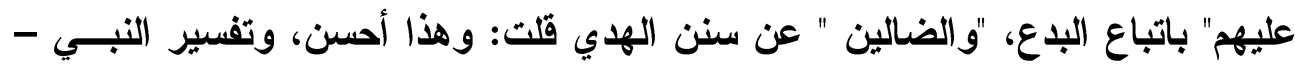

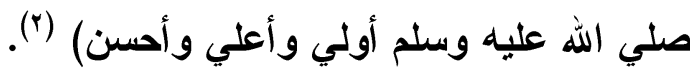
و الغضب من صفات البشر وهو معروف وقد اختلف العلماء في صفة الغضب بالنسبة

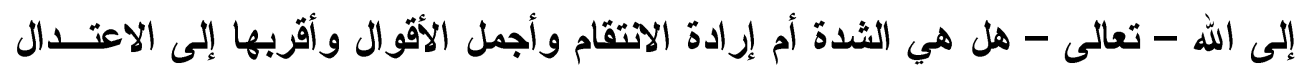

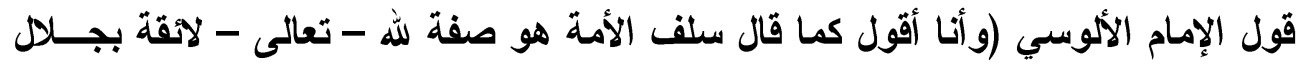
ذاته لا أعلم حقيقتها ولا كيف هي والعجز عن درك الإدر الك إدرالك والكلام فيــه كــالكلام في الرحمة حذو القذة فهما صفتان قديمتان له - سبحانه وتعالى) (َ). وقال الإمام البقاعي رحمه الله: -

(قوله -تعالى - "غير المغضوب عليهم " أي الأين نعاملهم معاملة الغضبان لمن وقع عليه غضبه، وتعرقت "غير " لتكون صفة للأين بإضافتها إلى الضد فكان مثل: الحركــة

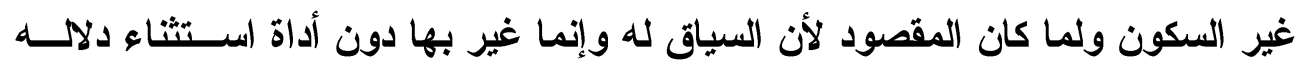

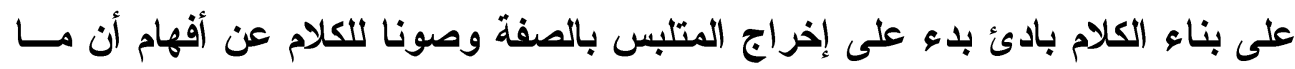

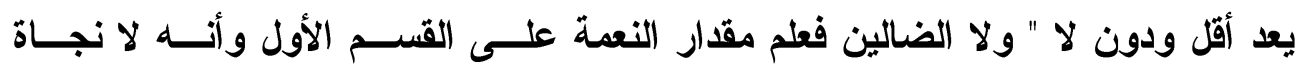
إلا باتباعهم وأن من حاد عن سبيلهم عامدا أو مخطئا شقي ليستمر أولو الجد عن ساق الاول ولهم

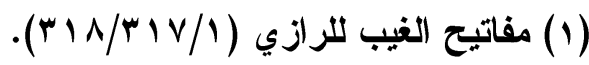

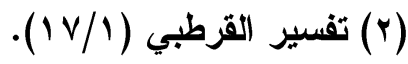

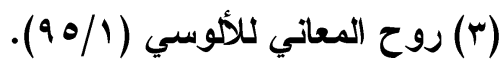




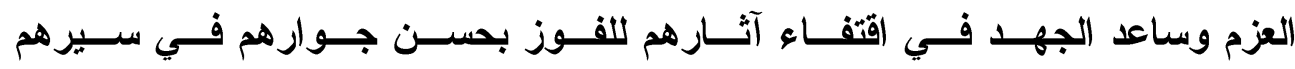

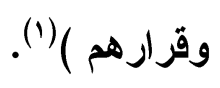

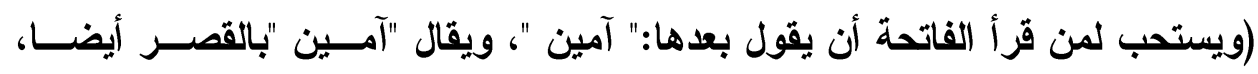

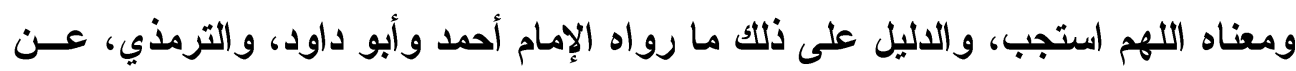

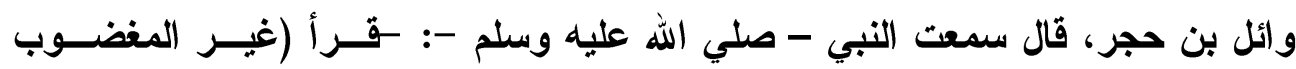

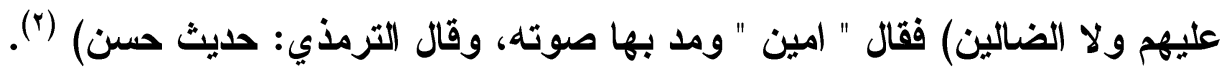

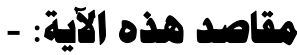

1-الاعتر اف بنعم الله عز وجل - وأجلها الهداية.

r-الاقتداء بالصالحين واجتناب مسالك الطالحين.

$$
\text { أسلوب عرض مقاصد الفاتحة }
$$

(الأسلوب هو الدذهب الكلامي الذي انفرد به المتكلم في تأدية معانيه ومقاصــده مــن

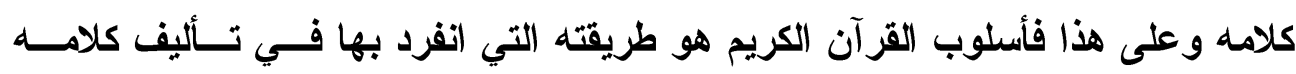

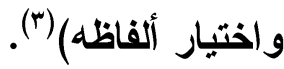

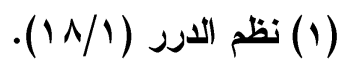

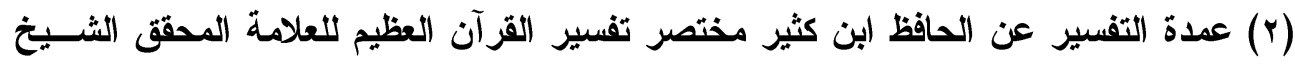

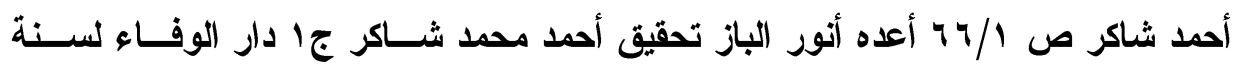

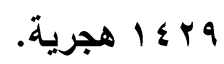
(r) مناهل العرفان في علوم القرآن للشيخ محمد عبد العظـيم الزرقـــي ص جr/N اب ط دار

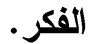


واستعير قلم الاستاذ الكبير محد عبد العظيم الزرقاني في بيان أسلوب سورة الفاتحة

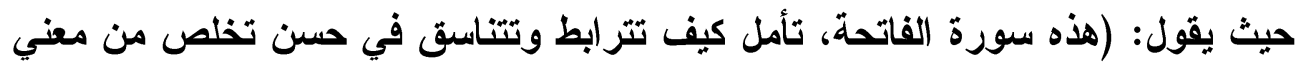

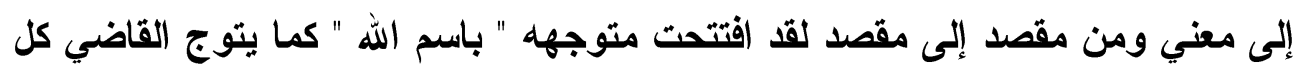

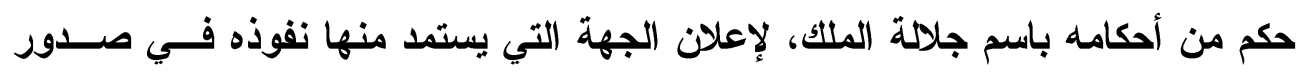

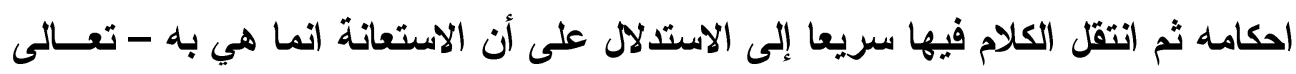

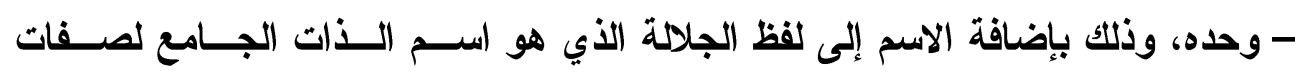

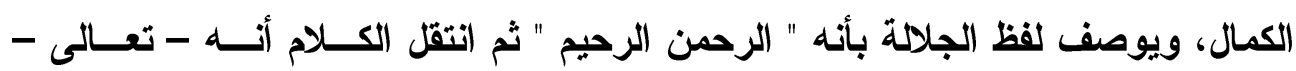

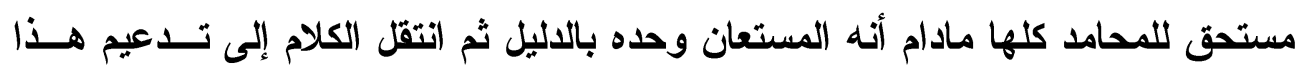

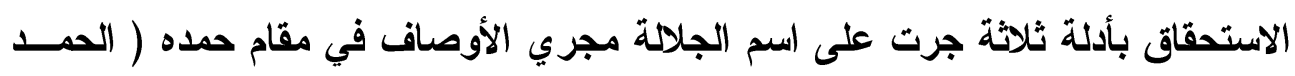

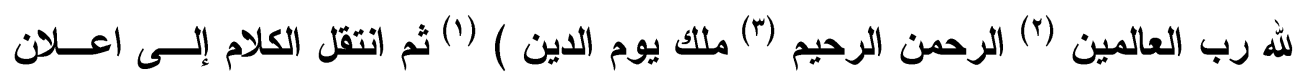

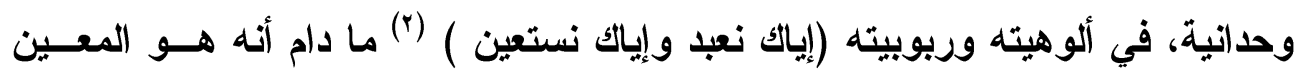

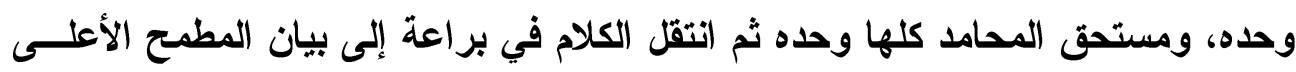

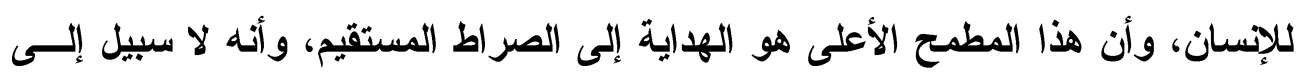

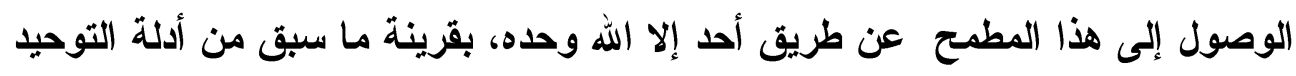

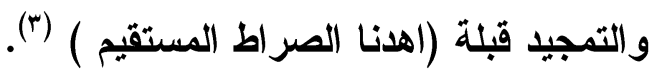
ثم انتقل الكلام من حيث لا تشعر أومن حيث تثعر إلى تقسيم الخلق بالنسبة إلى هذه

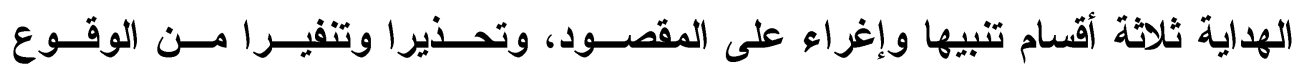

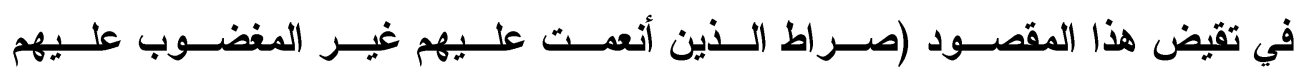

$$
\begin{aligned}
& \text { (1) الفاتحة (Y- ( ) ). } \\
& \text { (Y) الفاتحة (Y) (Y) }
\end{aligned}
$$

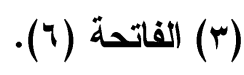


ولا الضالين ) (1). وإذا الناس أمام عينيك بين مـــعم عليـهـ بمعرفــة الحـق واتباعـهـ

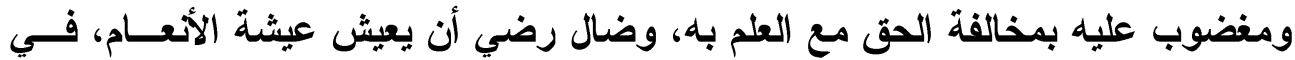
متاهة الجهالة والحيرة و الضلال، لا يكلف نفسه عناء البحث عن الحق ليتشرف بمعرفته ويسعد باتباعه. ثم تنظر في سورة البقرة، فإذا هي وما بعدها ترتبط بالفاتحسـة ارتبــاط المفصل بالمجمل فالهالية إلى صراط المستقيم صراط من أنعم الله عليهم مسن النبيـين

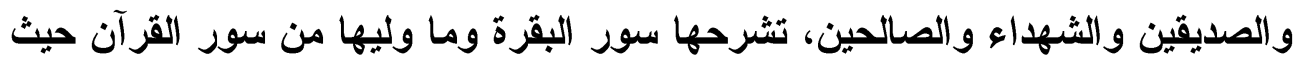

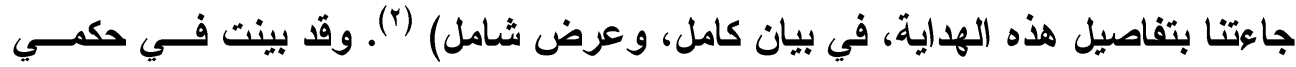
ذكر الآيات بعد سابقتها مقاصد أخري من الترغيب والترهيب وإقامة العقيدة واســتقامة السلوك إلى غير ذلك مما سبق بيانه. 


\section{الخاتمة}

من خلال هذا البحث تجلت أمور منها: -

1- اثثتمال الفاتحة على أمهات مقاصد القرآن الكريم لذلك سميتها جامعة المقاصد. r- تعظيم ثمرات دراسة المقاصد بالنظر إلى المفردات التي تدل عليها والعبارات

التي تنضمنها.

ب-تضمنت الفاتحة أصولا جاء بيانها في القرآن لذلك سميت بأم الكتاب أم القرآن. ـ -تجلت عظمة الأسلوب القرآني في عرض مقاصد هذه السورة والحكم الجليلة في ترتيب هذه المقاصد.

ه-إذا كانت المقاصد تعرف بتلبر الآيات فقد قدمت تفسيرا مجملا تتجلي بعده مقاصد

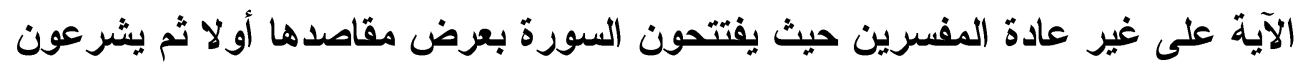
في تفسيرها فعلى من يتعرض لمقاصد السور الطول أن يسوق مجمل تفسير الآيات في الآي كل مقصد وعلى من يتعرض لتفسير السور معدودة الآي أن ينظر في الألفاظ ودلالاتها من خلال العبارة وما تتضمنه عن طريق الإثارة. 4-تجلي إعجاز القرآن في مجمله ومفصله حيث تري في الفاتحة جمال الإجمال دون اختلال ولا تري في غيرها ملل الإسهاب فكل في نظمه معجز أنه كلام الله وكفي. V-إذا كان على المؤمن أن يجدل ايمانه فها هي الفاتحة إذا استحضر المصلي بقلبه

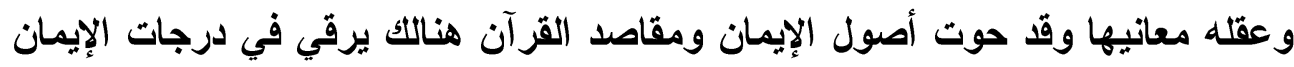
وتؤتي الصلاة ثمرتها وتتحقق للنفس سعادتها في الدارين. 


\section{المسادر والمراجع}

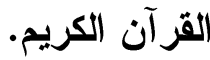

1- الجامع لأحكام القرآن الكريم تفسير القرطبي لأبي عبد الاه محد بن أحمد الأنصاري، تحقيق إيراهيم محمد الجمل.

r- الثيطان والإسان بين أوليائه وأعدائه للثيخ عبد الكريم الخطيب ط دار الفكر

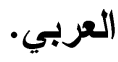

rــ الكثاف عن حقائق التززيل وعيون الأقاويل في وجوه التأويل لابي القاسم محمود ابن عمر الزمخثري الخوارزمي.

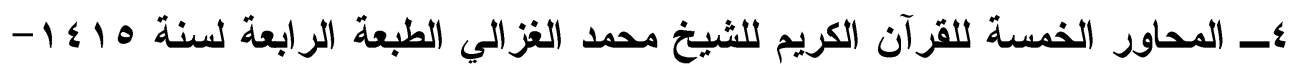

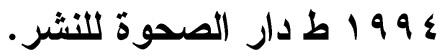

هـ ـ المصباح المنير للعلامة أحمد بن محمد بن على الفيومي المقرئ طبعة جديدة محققة اعتني بها الاستاذ يوسف الثيخ محمد المكتبة العصرية (بيروت - صيدا). T- - أمهات مقاصد القرآن لعز الدين كثنيط رسالة دكتوراه -الجزائر. V- أهداف كل سورة ومقاصدها في القرآن الكريم للاكتور عبد الله محمود شحاته

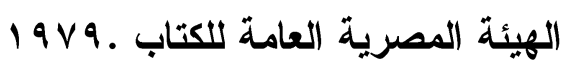

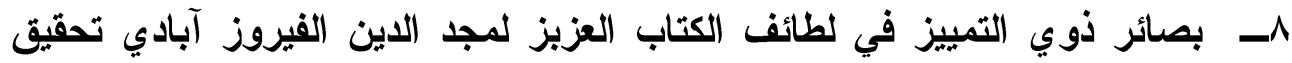

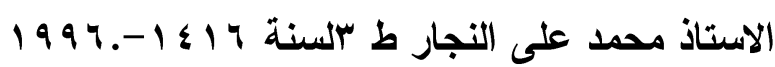

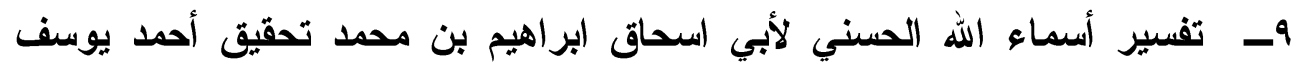

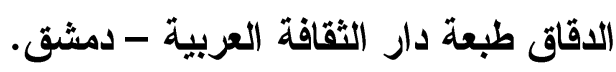

• اـ تفسير المراغي لصاحب الفضيلة الاستاذ الكبير المرحوم احد مصطفي المراغي

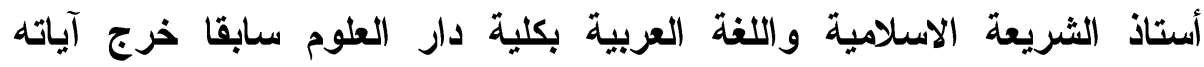
وأحاديثه باسل عيون السود ط دار الكتب العلمية - بيروت - لبنان. 


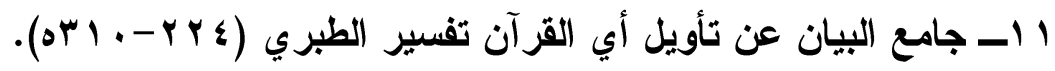
rا

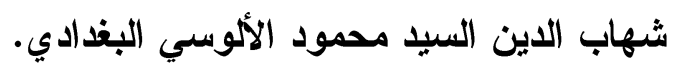

rا إ- صحيح البخاري لأبي عبد الله محمد ابن إسماعيل ابن إبراهيم ابن المغيرة البخاري ط دار الأرقم بيروت.

؛ أـ صحيح مسلم بشرح النووي ط الثقافة العربية. ها-_ غرائب القرآن ورغائب الفرقان لنظام الدين الحسن بن محمد بن الحسبن النيسابوري تحقيق حمزة النشرتي.

14 إ- مختار الصحاح للثيخ الامام محمد بن أبي بكر بنعبد القادر الرازي طد دار المنار.

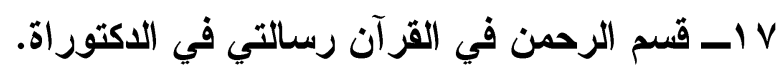

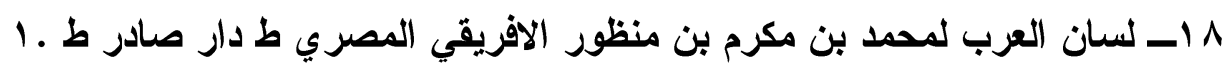

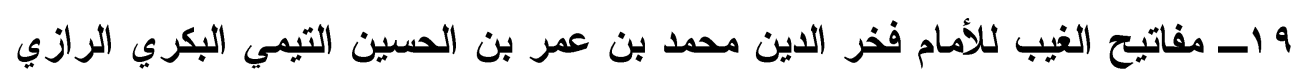

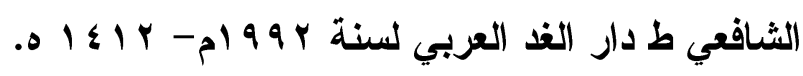

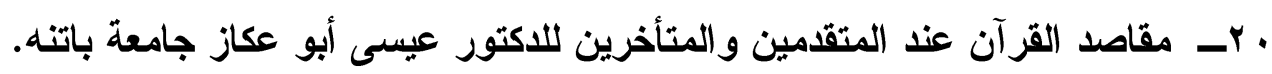

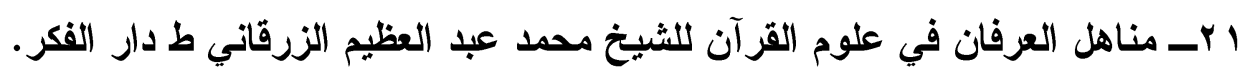

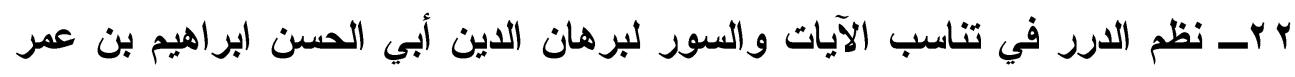
البقاعي ط دار الكتب بيروت إلى غير ذلتك. 
سورة الفاتحة جامعة المقاصد وناجعة القاصد

فهرس الموضوعات

\begin{tabular}{|c|c|}
\hline |لصفمة & الإوفوع \\
\hline vr & المقدمة . \\
\hline$V \leq$ & أولَا: - التعريف بالمقاصد وأهميتها. \\
\hline$\checkmark v$ & ثانيا: - التعريف بسورة الفاتحة . \\
\hline $11 \varepsilon$ & الخاتمة . \\
\hline 110 & المصادر والمر اجع . \\
\hline $11 \mathrm{~V}$ & فهرس الموضوعات . \\
\hline
\end{tabular}

